Saint Louis University School of Law

Scholarship Commons

All Faculty Scholarship

2013

\title{
Utopian Visions toward a Grand Unified Global Income Tax
}

Henry Ordower

Saint Louis University School of Law

Follow this and additional works at: https://scholarship.law.slu.edu/faculty

Part of the Tax Law Commons

\section{Recommended Citation}

Ordower, Henry, Utopian Visions Toward a Grand Unified Global Income Tax (2013). Florida Tax Review, Vol. 14, No. 5, 361 - 418 (2013).

This Article is brought to you for free and open access by Scholarship Commons. It has been accepted for inclusion in All Faculty Scholarship by an authorized administrator of Scholarship Commons. For more information, please contact erika.cohn@slu.edu, ingah.daviscrawford@slu.edu. 
Utopian Visions toward a Grand Unified Global Income Tax

Henry Ordower

Professor of Law

Saint Louis University School of Law

St. Louis, Missouri, USA 
A grand unified global income tax (GUGIT) may prove as elusive as the grand unified theory (GUT) that physicists have sought for many years. ${ }^{1}$ Yet, just as recent discoveries bring physicists closer to a GUT, ${ }^{2}$ developments in the international financial and tax worlds may move a GUGIT into imaginable reach. Since the discussions of a global unified corporate tax base in the early 1990s, ${ }^{3}$ significant and often surprising changes have taken place in the financial and tax worlds. To name just a few of those changes, the European Union (EU) expanded eastward to include many of the former Soviet satellite countries; ${ }^{4}$ seventeen member states of the EU, ${ }^{5}$ including several from the eastward expansion, ${ }^{6}$ eliminated their national currencies in favor of a single common currency, ${ }^{7}$ the Organization for Economic Cooperation

\footnotetext{
${ }^{1}$ A Grand Unified Theory (GUT) refers to attempts to explain electromagnetic, strong and weak forces under a single theory. To date, physicists have not accounted successfully for the three forces in a single theory. Dan Hooper, Nature's Blueprint: Supersymmetry and the Search for a Unified Theory of Matter and Force 137-38 (ebook edition) (New York 2008).
}

The search for a GUT began long before construction of the CERN Large Hadron Collider began. CERN is the acronym for Conseil Européen pour la Recherche Nucléaire, the European Organization for Nuclear Research. CERN built the Large Hadron Collider (LHC) on the Switzerland-France border. The collider became operational in 2008 but CERN does not plan to operate it for significant research until 2014. Information about CERN and the Large Hadron collider is available at http://public.web.cern.ch/public/en/About/About-en.html. When fully operational, the collider should provide experimental evidence that will confirm or refute many theoretical positions concerning the nature and interaction of subatomic particles. The failure to produce conclusive experimental evidence that a GUT exists does not deter particle physicists from continuing to strive for a theory, conduct particle collision experiments and develop applications for the data from the particle accelerators.

${ }^{2}$ Recently, CERN scientists announced a breakthrough as they discovered a particle that may be the Higgs boson. On Wednesday, July 4, 2012, scientists at CERN announced the possible discovery of the Higgs Boson particle that would be critical to the GUT at the LHC. THE NEW YORK Times A1 (July 5, 2012). According to an explanation on the CERN website, the Higgs boson is the - possibly no longer hypothetical - particle giving gave mass to the massless particles the Big Bang created. http://public.web.cern.ch/public/en/science/higgs-en.html

${ }^{3}$ Reuven S. Avi-Yonah, "Slicing the Shadow: A Proposal for Updating U.S. International Taxation," TAX NoteS, Mar. 15, 1993, p. 1511; Eric J. Coffill and Prentiss Wilson Jr., "Federal Formulary Apportionment as an Alternative to Arm's Length Pricing: From the Frying Pan to the Fire?" TAX Notes, May 24, 1993, p. 1103. William J. Wilkins and Kenneth W. Gideon, Congress: You Wouldn't Like Worldwide Formula Apportionment, Tax Notes 1351 (June 11, 2012) (republished from the Dec. 5, 1994 issue of TAX NOTES) (marshaling arguments against worldwide formulary apportionment of corporate business income and labeling the concept a "design for disagreement."); and Paul R. McDaniel, Formulary Taxation in the North American Free Trade Zone, 49 TAX L. REV. 691 (1994) (describing unitary taxation for North America). More recent discussion of worldwide taxation and cross-border formulary apportionment appears in the literature on reform of U.S. taxation, including Julie Roin, Can the Income Tax Be Saved? The Promises and Pitfalls of Adopting Worldwide Formulary Apportionment, 61 Tax L. Rev. 169 (2008); Reuven S.Avi Yonah, Kimberly A. Clausing \& Michael C. Durst, Allocating Business Profits for Tax Purposes: A Proposal to Adopt a Formulary Profit Split, 9 Fla. TAX. REV. 497 (2009); Susan C. Morse, Revisiting Formulary Apportionment, 29 Va. Tax. Rev. 593 (2010).

${ }^{4}$ In 2004, the Czech Republic, Estonia, Latvia, Lithuania, Hungary, Poland, Slovakia and Slovenia joined the EU, as well as non-Soviet satellite countries Cyprus and Malta. Romania and Bulgaria joined the EU in 2007.

http://ec.europa.eu/enlargement/the-policy/from-6-to-27-members/index_en.htm

${ }^{5}$ EC, Economic and Financial Affairs, The euro (available at

http://ec.europa.eu/economy_finance/euro/index_en.htm) (showing Belgium, Germany, Ireland, Spain, France, Italy, Luxembourg, the Netherlands, Austria, Portugal, Finland, Greece, Slovenia, Cyprus, Malta, Slovakia, and Estonia as euro zone countries).

${ }^{6}$ Id. (Slovenia, Slovakia and Estonia)

${ }^{7} I d$. The Euro became available for financial transactions in 1999 with banknotes and coins appearing in 2002.

Eleven EU states adopted the Euro in 1999 with an additional six joining the currency union at various times later. Countries using the euro retain control over their own economies but "they undertake to adhere to commonly agreed 
and Development (OECD) shamed and coerced many tax havens into cooperating in the exchange of information in tax matters; ${ }^{8}$ Switzerland and Liechtenstein began to negotiate limitations on the protection they offered to foreign investors under their financial institution secrecy laws; Russia's suspension of payments on its sovereign debt in 1998 driving the failure of major investment pools and their managers ${ }^{9}$ and the subprime crisis in the United States in 2007 leading to the financial crisis in $2008^{10}$ threatened to undermine the world economy and brought the concept of systemic risk to prominence; in the United States, the 2008 financial crisis led to enactment of systemic risk focused regulation of the economy; ${ }^{11}$ the Securities Exchange Commission (SEC) adopted a proposed rule to converge and convert financial reporting in the United States ${ }^{12}$ from generally accepted accounting principles ${ }^{13}$ to international financial reporting standards $;^{14}$ and the European Commission (EC) took the first definitive step toward cross border combined income tax reporting in the EU. ${ }^{15}$ While barriers to development of a working GUGIT may be just as formidable as barriers to discovery of a GUT, this paper argues that each step toward a GUGIT is a step toward tax transparency, distributional fairness, and public acceptance of the legitimacy of the income tax system.

Amidst the clamor in recent decades to abandon historically progressive taxation ${ }^{16}$ in favor of proportional and regressive taxation, ${ }^{17}$ the hum of progressive taxation remains faintly

rules on public finances known as the Stability and Growth Pact."

http://ec.europa.eu/economy_finance/euro/index_en.htm.

${ }^{8}$ The initial step was the issuance of a report on tax havens, OECD, HARMFUL TAX COMPETITION AN EMERGING GLOBAL ISSUE (1998) (available at http://www.oecd.org/dataoecd/33/0/1904176.pdf).

${ }^{9}$ Long Term Capital Mangement.

${ }^{10}$ For a discussion of the events leading to the financial crisis, see National Commission on the Causes of the Financial and Economic Crisis in the United States, THE FINANCIAL CRISIS INQUIRY REPORT (Washington DC, 2011) (available at http://fcic-static.law.stanford.edu/cdn_media/fcic-reports/fcic_final_report_full.pdf).

${ }^{11}$ Dodd-Frank Wall Street Reform and Consumer Protection Act, Pub L 111-203 (7-10-2010).

${ }^{12}$ SEC Proposed Rulemaking, Roadmap for the Potential Use of Financial Statements Prepared in Accordance with International Financial Reporting Standards (IFRS) by U.S. Issuers, Rel. Nos. 33-8982; 34-58960 (Nov. 14, 2008 ). More recently, however, the SEC's support for a U.S. transition to IFRS has wavered. SEC, Final Staff Report, Work Plan for the Consideration of Incorporating International Financial Reporting Standards into the Financial Reporting System for U.S. Issuers (July 13, 2012) (available at

http://www.sec.gov/spotlight/globalaccountingstandards/ifrs-work-plan-final-report.pdf) (not recommending adoption of IFRS, but recommending further work toward convergence of GAAP and IFRS. See further discussion infra note 218 and accompanying text.

${ }^{13}$ Referred to as GAAP and including fairly detailed rules for financial reporting.

${ }^{14}$ Referred to as IFRS and based upon general principles of reporting rather than specific rules.

15 The first meeting of the Common Consolidated Corporate Tax Base (CCCTB) Working Group (CCCTB WG) took place on November 24, 2004. The agenda for that meeting is available at http://ec.europa.eu/taxation_customs/taxation/company_tax/common_tax_base/article_2336_en.htm. The EC's establishment of its CCCTB WG was the impetus to the commentary,

${ }^{16}$ The classic work cataloging arguments for progressive taxation is Walter J. Blum and Harry Kalven, Jr., THE UnEASY CASE FOR PROGRESSIVE TAXATION (Chicago, 1953). The German Constitutional Court, in holding that taxpayers whose jobs and family structure required them to maintain two residences permanently must be treated the same as taxpayers whose secondary residence was purportedly temporary but who might have a series of temporary placements, observed with respect to horizontal and vertical equity that: “... taxpayers who have the same ability to pay should be taxed equally (horizontal tax equity), while (in the vertical direction) taxation of higher incomes should be measured against the taxation of lower incomes. Decision of December 4, 2002, BVerfGE 107, $27,46$. Author's translation. Emphasis added. The German reads: “... Steuerpflichtige bei gleicher Leistungsfähigkeit auch gleich hoch zu besteuern (horizontale Steuergerechtigkeit), während (in vertikaler Richtung) die Besteuerung 
audible. $^{18}$ Tax competition and mobility of capital have led many countries to decrease the tax burden on capital and capital income and increase the burden on the less mobile tax bases of labor ${ }^{19}$ and consumption. ${ }^{20}$ Some commentators argue that taxing capital at all is inefficient as it causes taxpayers to engage in tax arbitrage ${ }^{21}$ and shift capital income to low tax jurisdictions, often through favorable transfer prices. $^{22}$

Transfer pricing has proven particularly problematic for tax collectors. Transfer pricing refers to the price that one member of a group of related entities (or individuals and entities) charges another member of the group for goods or services where the group members are in different jurisdictions. Since the parties to the transaction are related, they do not negotiate at arms' length in determining the correct price for the goods or services but may select a price that places the income from the transaction in the jurisdiction extracting the lowest tax. ${ }^{23}$ Most high tax jurisdictions require that the taxpayer establish that its transfer prices are the prices that it would pay or receive, as the case may be, in an arms' length negotiation. ${ }^{24}$ Satisfactorily combatting artificiality in transfer prices often has proven challenging and costly for tax collectors. Taxpayers having significant income from exploitation of their intellectual and other

höherer Einkommen im Vergleich mit der Steuerbelastung niedriger Einkommen angemessen sein muss.” For further discussion of the decision, see Henry Ordower, Horizontal and Vertical Equity in Taxation as Constitutional Principles: Germany and the United States Contrasted, 7 Fla. TAX REV. 259, 303-5 (2006). But see James Repetti and Diane Ring, HoRIZONTAL EQUITY REvisited, 13 Fla. Tax Rev. 135 (2012) (reviewing the literature and arguing that horizontal equity has not normative content and most likely is only part of the vertical equity concept).

${ }^{17}$ OECD Tax Policy Studies, Fundamental Reform of Personal Income Tax 7 (Paris, 2006) (identifying trends in tax rates in OECD countries):Jane G. Gravelle, The Flat Tax, Value-Added Tax, and National Retail Sales Tax: Overview of the Issues, Congressional Research Service 7-5700, RL 32603 (2008) (identifying issues and distributional concerns in tax restructuring); Alvin E. Hall and Alvin Rabushka, THE FLAT TAX (Stanford 1995) (arguing for a flat rate of tax with an exemption at the lower end); Michael J. Graetz, 100 MILLION UNNECESSARY RETURNS: A SiMPLE, FAIR, AND COMPETITIVE TAX PLAN FOR THE UNITED STATES (New Haven 2008) (proposing a value added tax and exempting all but the highest income individuals from any income tax in order to preserve minimal progressivity).

${ }^{18}$ Warren E. Buffett, Stop Coddling the Super-Rich, THE NEW YoRK TIMES A 21 (August 15, 2011) (editorial arguing that very wealthy individuals are under-taxed especially on their income from capital).

${ }^{19}$ Roger H. Gordon, Taxation of Capital income vs. labour income: An overview in Sijbren Cnossen ed., TAXING CAPITAL INCOME IN THE EUROPEAN UNION: ISSUES AND OPTIONS FOR REFORM 15, 24 (Oxford 2000).

${ }^{20}$ For example, the share of governmental revenues that the value added tax produced in Sweden from the year 2000 to 2010 increased gradually from 16.88 percent to 21.29 percent. European Commission Taxation and Customs Union, available at http://ec.europa.eu/taxation_customs/tedb/taxDetail.html?id=531/1330473600\&taxType=VAT . During the same period, the personal income tax in Sweden accounted for a decreasing percentage of tax revenue, declining from 29.86 percent to 25.28 percent. $I d$. available at http://ec.europa.eu/taxation_customs/tedb/taxDetail.html?id=1701/1330905600\&taxType=PIT. Taxes on capital decreased even more with the elimination of both the wealth tax and the estate tax. In addition, recent financial crises and risks that governments like Greece and Spain will default on sovereign debt suggest that governments are relying more heavily on sovereign debt to offset shortfalls in tax revenue.

${ }^{21}$ Tax arbitrage refers to the practice of consciously exploiting difference in tax rules from one taxing jurisdiction to another by constructing transactions to capture taxpayer beneficial elements of differing tax rules. See, generally, Gene Steuerle, Tax Shelters and Tax Arbitrage, 95 Tax Notes 1249 (May 20, 2002) (explaining tax arbitrage and its leveraging effect).

${ }^{22}$ See, generally, Reuven S. Avi-Yonah, Diane M. Ring, and Yariv Brauner, U.S. INTERNATIONAL TAXATION: CASES AND MATERIALS at 192 et seq. (New York 2011).

${ }^{23} I d$.

${ }^{24}$ OECD, TRANSFER Pricing Guidelines FOR Multinational ENTERPRISES AND TAX ADMinistrations (2010). 
intangible properties, including goodwill, have been particularly adept at establishing transfer prices that place that income in low tax jurisdictions. ${ }^{25}$

In addition to the efficiency argument and the impact of tax competition are arguments against taxing capital income because much capital income is not real income since it is attributable to the effect of inflation and because taxing capital is taxing labor a second time since taxes on capital are taxes on savings of the income from labor. ${ }^{26}$ The arguments for not taxing income from capital are unpersuasive. If the tax reached only the current portion of capital income, interest for the use of capital, for example, only that part of the interest in excess of the nominal rate for the use of capital would be attributable to inflation. That same excess manifests itself in wages and living costs, however, as well as the return on capital. The argument not to tax the inflation portion of yield on capital is equally an argument not to tax part of wage increases. The inflation argument with respect to capital appreciation is also flawed since the simple fix to bring that in line with wage increases is elimination of the realization requirement for taxing gains on property and substituting a broad mark to market regime for all assets. ${ }^{27}$ The argument that capital represents savings from labor income, so that taxing capital income is taxing frugal wage earners a second time, ${ }^{28}$ also is weak. Most wage earners have little opportunity to save, so that savings and investment take place primarily in the higher income groups and much is from reinvested capital income. ${ }^{29}$ Moreover, the higher earning groups sometimes even find ways to convert income from their services into preferred capital income. $^{30}$

Transfer pricing and other tax arbitrage opportunities would diminish substantially if there were no income tax on capital but only at the cost of increased value added taxes on consumption and increased taxes on labor tax sufficient to replace the lost revenue from elimination of the tax on capital. The presence of the high value added taxes in turn would generate incentives to purchase and consume outside the high tax jurisdiction whenever possible. High taxes on wages create incentives at all levels to evade taxes by not reporting cash and barter income, ${ }^{31}$ and, at high wage levels, to convert income from services into income from capital

\footnotetext{
${ }^{25}$ The OECD recently announced a discussion draft of transfer pricing guidelines for intangibles. OECD Working Party No. 6 releases a discussion draft on the Transfer Pricing Aspects of Intangibles (available at http://www.oecd.org/document/41/0,3746,en_2649_33753_50509929_1_1_1_1,00.html) (June 6, 2012). The final report from the working group would supplement the OECD, TRANSFER PRICING GUIDELINES, $i d$. .

${ }^{26}$ Gordon, supra note 19, at 17 - 21(surveying the academic literature arguing against taxing income from capital). .

${ }^{27}$ Compare, I.R.C. $\$ 1256$ (marking to market and including in income (or loss) the annual appreciation or depreciation in the value of certain commodities and other gains).

${ }^{28}$ Gordon, supra note 19, at 19.

${ }^{29}$ Bureau of Labor Statistics, Consumer Expenditure Survey available at http://www.bls.gov/cex/tables.htm (providing data on expenditures in various income groups in the U.S.). .

${ }^{30}$ Consider the recent discussion of carried interests that found its way into the 2012 Presidential campaign. See, generally, See, generally, Victor Fleischer, Two and Twenty: Taxing Partnership Profits in Private Equity Funds, 83 N.Y.U. L. REV. 1, 57-58 (2008) (arguing that some or all the profits a partnership allocates to service provider partners is ordinary income from services rather than a distributive share of the partnership's income).

${ }^{31}$ The underground or shadow economy refers to payments that do not use the national or international banking system in order to avoid detection and taxation. Friedrich Schneider \&Dominik Enste, HIDING IN THE SHADOWS: THE GROWTH OF THE UNDERGROUND ECONOMY 1-5 (2002) (explaining the concept of the shadow economy, estimating the underground economy around the world, estimating the underground economy at $10 \%$ of gross domestic product in the United States during the 1999-2001 period, and identifying steep growth from 1970-2000).
} 
wherever possible. ${ }^{32}$ Individuals whose provision of services is not tied to the specific physical location also may relocate physically to a lower tax jurisdiction. ${ }^{33}$ Individuals with the ability to relocate in that manner are likely to come from the high income or wealth segments of the society.

This paper will argue that a GUGIT likewise solves the problem of tax arbitrage and transfer pricing without sacrificing the progressive income tax. A GUGIT would diminish opportunities to engage in tax arbitrage because tax rules would be uniform across jurisdictions. A GUGIT also would eliminate most opportunities to exploit transfer pricing since the GUGIT would use a robust taxpayer group concept ${ }^{34}$ and exclude all intra-group transactions from the tax base and the formula for distributing the base among nations. Members of a taxpayer group would have a group tax base that the GUGIT would apportion among the members of the group. ${ }^{35}$

Seeking a GUGIT in the 2012 world is a far different matter from seeking a GUGIT in 1994. In 2012, the concept, if not all the details, of a Common Consolidated Corporate Tax Base (CCCTB) has embedded itself in the world's largest aggregate economy, the EU. ${ }^{36}$ The EC proposed the CCCTB Working Group's (CCCTB WG) recommendations for an elective common consolidated corporate tax base $^{37}$ and the European Parliament (EP) modified and adopted the proposal for the enactment of a mandatory, rather than the EC's proposed voluntary, CCCTB with a five year phase in. ${ }^{38}$ Unlike the 1994 world that was nearly devoid of international cooperation on tax transparency and information sharing, ever increasing

${ }^{32}$ Supra note 30 .

${ }^{33}$ See discussion infra in part 3.C.

${ }^{34}$ Infra part 3.B.

${ }^{35}$ Infra part 3.A. B.

${ }^{36}$ The combined member states of the EU have the largest aggregate gross domestic product in the world, constituting nearly twenty percent of the worldwide GDP. Central Intelligence Agency, The World Fact Book (updated weekly online at https://www.cia.gov/library/publications/the-world-factbook/geos/xx.html) ( estimating the world purchasing power GDP at approximately \$79 trillion in 2011 and the EU GDP at \$15.4 trillion, with the U.S. a close second at $\$ 15$ trillion).

${ }^{37}$ See, European Commission, Brussels, COM(2011) 121/4, 2011/0058 (CNS)Proposal for a COUNCIL DIRECTIVE on a Common Consolidated Corporate Tax Base (CCCTB) (2011) at 14, available at http://ec.europa.eu/taxation_customs/resources/documents/taxation/company_tax/common_tax_base/com_2011_12 1_en.pdf. (CCCTB Proposal in the following). The EC describes the proposal on its website at http://ec.europa.eu/taxation_customs/taxation/company_tax/common_tax_base/index_en.htm as follows:

The European Commission on 16 March 2011 proposed a common system for calculating the tax base of businesses operating in the EU.

The proposed Common Consolidated Corporate Tax Base (CCCTB), would mean that companies would benefit from a "one-stop-shop" system for filing their tax returns and would be able to consolidate all the profits and losses they incur across the EU. Member States would maintain their full sovereign right to set their own corporate tax rate.

${ }^{38}$ EP, Legislative resolution of 19 April 2012 on the proposal for a Council directive on a Common Consolidated Corporate Tax Base (CCCTB) (COM(2011)0121 - C7-0092/2011 - 2011/0058(CNS) (available at http://www.europarl.europa.eu/sides/getDoc.do?type=TA\&reference=P7-TA-2012-0135\&language=EN\&ring=A72012-0080) (EP CCCTB resolution). 
international cooperation on tax information sharing characterizes the 2012 world. ${ }^{39}$ Yet, despite advances in information sharing, tax competition and tax avoidance have rendered the need for better assessment and collection methods compelling. The primary goals of those improved methods are to prevent wealthier taxpayers from avoiding tax and to restore public confidence that the distribution of tax burden is fair. Without some fundamental change in the income tax system, the public perception of the tax system as favoring the wealthy and powerful is likely to continue to grow ${ }^{40}$ as will the shadow economy and its accompanying loss of tax revenue. ${ }^{41}$ A GUGIT just might offer the solution as it diminishes concealment of income and limits cross border tax arbitrage. To the extent people who participate extensively in the underground economy do so to level the playing field with wealthier people who are able to capture favorable tax treatment within existing tax systems, the GUGIT may diminish the underground economy as well.

This paper offers an overview of many of the issues that a GUGIT raises and explains why current global trends suggest that most of those issues no longer are a barrier to adoption of a GUGIT. The paper does not provide a detailed GUGIT proposal but builds on the work of the CCCTB WG and its detailed proposal for a CCCTB. ${ }^{42}$ Part 1 of this paper defines the GUGIT concept and describes its contours and limitations. Part 2 confronts the critical issue of national sovereignty under a centralized reporting and collection system. Part 2 also addresses incentivizing countries to accommodate a GUGIT as well as the more general considerations of the relinquishment of personal freedom that would be essential to the successful operation of the GUGIT. Part 3 reviews several of the technical objections to a GUGIT including the methodology for allocating and apportioning income among jurisdictions, currency conversions, accounting and language translation matters. Part 4 argues that international agreement to a uniform set of tax rules is not quite so unattainable as it might seem because national tax laws tend to converge internationally in any event. Nations increasingly borrow successful elements from the tax laws of other countries and follow the models that other nations establish. ${ }^{43}$ Part 5 concerns itself with the economic displacements and revenue losses that are likely to arise from transition to a GUGIT. Part 6 concludes that economic globalization has created the conditions essential to development of a global tax system. Converging income tax rules internationally make it possible to negotiate uniform rules while acceptance of international cooperation on information sharing in tax matters has become sufficiently established and essential to prevent tax avoidance that national sovereignty as a barrier to a GUGIT quickly is weakening. A GUGIT while utopian (or dystopian if the GUGIT would limit the taxpayer's planning

\footnotetext{
${ }^{39}$ OECD, Global Forum on Transparency and Exchange of Information for Tax Purposes, Progress Report to the G20 (Global Forum Progress Report) (Los Cabos 2012) (available at http://www.oecd.org/dataoecd/19/8/50630814.pdf) (identifying significant increase in tax transparency and automatic information exchange including jurisdictions that formerly were non-cooperative tax havens).

${ }^{40}$ See, generally, Henry Ordower, The Culture of Tax Avoidance, 55 SAINT LouIS U L J 47, 115-125 (2010) (discussing public perceptions of tax rates and fairness and expressing general willingness to avoid and often evade taxes).

${ }^{41}$ See supra note 31 discussing the underground economy.

${ }^{42}$ CCCTB Proposal, supra note 37.

${ }^{43}$ Compare the proliferation of general anti-avoidance rules during the most recent year tax history. See, generally, Ordower, The Culture of Tax Avoidance, supra note 40, at 94-103. 
opportunities) also may be possible so that development of a model and commencement of negotiations lies in the near, not distant, future.

Part 1. What is a GUGIT and how would it work? A GUGIT provides rules to identify the taxpayer, rules to compute the taxpayer's income, and rules to distribute the power to tax the taxpayer's income among the jurisdictions in which the taxpayer receives or accrues income. First the GUGIT must determine the identity of the taxpayer. The taxpayer might be a single individual or entity or a more complex combination of multiple individuals or entities. Once the GUGIT identifies the taxpayer, it may determine the tax base that it will distribute under a comprehensive set of uniform rules of inclusion in and exclusion from income, as well as rules for characterization of special types of income -- capital income, for example. ${ }^{44}$ In addition, a GUGIT uniformly sorts a taxpayer's expenditures among currently deductible expenses, capital expenditures, and expenditures unrelated to income production. With respect to capital expenditures the GUGIT governs when the taxpayer may recover those expenditures for tax purposes either by allowing a gradual recovery under uniform rules for depreciation and amortization, by absorbing the expenditures into inventory cost recoverable as part of the cost of goods the taxpayer sells, or by including the expenditure in the tax cost of property that the taxpayer recovers for tax purposes when the taxpayer disposes of the property. With respect to those expenditures that do not relate to the production of income, the GUGIT reserves those items for national or local decisions on deductibility. After determining the taxpayer's income and reducing it by the deductible and currently recoverable amounts of expenditures, the GUGIT distributes the tax base under a uniform set of rules among all countries in which the taxpayer produces income. $^{45}$

Each country might provide additional deductions for the taxpayer's non-income producing expenditures, charitable contribution deductions, for example, and possibly other adjustments unrelated to the production of income - personal deductions, a subsistence minimum free of tax with respect to its share of the taxpayer's tax base. ${ }^{46}$ Each country would impose its income tax on the net amount remaining after those deductions. Current differences among countries in the defining expenditures as personal and most likely non-deductible or related to

\footnotetext{
${ }^{44}$ Many income tax systems distinguish income from capital from income from labor and tax the different types of income at different rates. The US, for example, taxes gain from the sale or exchange of capital assets that a taxpayer has held for more than a year and certain dividends at a lower rate of tax than it taxes income from labor. Section 1(h) of the Internal Revenue Code of 1986, as amended (the "Code," constituting the tax laws of the U.S., Title 26 of the United States Code). This paper refers to provisions of the Code as I.R.C. § followed by a number. Germany also taxes capital gain at a favorable rate relative to labor income but taxes other income from capital, including interest, royalties, and dividends at the same favored rate. Einkommensteuergesetz vom 8. Oktober 2009, als geändert (EStG) (Income Tax Law of 10/8/09, as amended) (available at http://www.gesetze-iminternet.de/bundesrecht/estg/gesamt.pdf) § 2(1) 5. (capital as a tax class); § 20 (defining capital wealth); § 32d (imposing a 25 percent preferential rate on income from capital).

${ }^{45}$ Part 3 infra will provide more detail on the structure of the uniform tax base and its shares.

${ }^{46}$ Where a taxpayer is subject to tax in multiple jurisdictions, status deductions or exemptions like personal exemptions and standard deductions assure that each taxpayer retains an amount of income free from tax. In order to prevent duplication of those items in multiple jurisdictions, countries would allocate the items in proportion to their respective shares of the tax base. Most states of the U.S. currently do that type of allocation with their personal exemption amounts, for example, Illinois under 35 ILCS 5/204.
} 
income production and deductible or capitalizable might result in difficult negotiations toward a uniform rule, but, once settled, there would be a rule applicable universally. ${ }^{47}$

Under stabile global rules, the economic displacements that have accompanied the frequent changes in national tax laws stop. ${ }^{48}$ The tax future becomes predictable, so that pricing of property and services need no longer anticipate tax regulatory changes. Individuals and entities may adjust their operations to accommodate those stabile rules. Predictable outcomes even if dystopian to some or many participants in the world economy seem preferable to uncertainty. Governments need only adjust their tax rates to raise necessary revenue as changes in tax rules become a function of worldwide negotiation rather than local political considerations.

A uniform base should diminish much tax competition among nations. Cross border tax arbitrage to exploit characterization differences would disappear. While the GUGIT would not regulate the rate of tax that a country might impose on capital income, for example, it would fix the definition of capital income applicable in all jurisdictions. ${ }^{49}$ Without regard to location, expensing and rules of capital recovery through amortization and depreciation would be identical as would rules governing capitalization of expenditures. No country would be able to use favorable rates of depreciation, current expensing, or income exclusion from specific activities in order to attract investment.

Taxpayers may continue to shift portions of their tax base to lower tax jurisdictions in order to diminish their tax burdens. However, the GUGIT distributes income among jurisdictions on the basis of measurable factors so that shifting income means shifting those factors to the lower rate jurisdiction. ${ }^{50}$ In apportioning business income among jurisdictions, both the states of the United States and the CCCTB proposal rely on factors that include sales and, in most instances, property and payroll. ${ }^{51}$ A taxpayer wishing to shift income to a lower rate jurisdiction would have to shift its production or relinquish sales opportunities in higher tax

\footnotetext{
${ }^{47}$ For example, commuting expenses in the U.S. are personal and not deductible as business expenses, I.R.C. §262, (although when the employer pays them, I.R.C. $\$ 132(a)(5)$, the employer may deduct the payment, but the employee does not have to include them in her income) while in Germany commuting expenses are deductible business expenses subject to a statutory limit, EStG, supra note 44, § 9(1) 4. Similarly, considerable variations of the treatment of child care expenses exist, sometimes in a single tax system. In the U.S., there is a partial tax credit and also an exclusion if the employee pays for the child care with cafeteria plan funds under I.R.C. $§ 125$. Two-thirds of childcare costs (not to exceed $4000 €$ per child) for childcare to age 14 are deductible in Germany. EStG $\S 10(1) 5$.

${ }^{48}$ See discussion of economic displacement infra in part 5.

${ }^{49}$ Many jurisdictions tax capital income at a preferential rate, but the jurisdictions currently do not define capital income uniformly from jurisdiction to jurisdiction. See note 44 supra.

${ }^{50}$ Apportionment of income under any formula still may give rise to disputes. See, for example, Peter L. Faber, International Formulary Apportionment Is Not a Panacea, 136 Tax Notes 615 (July 30, 2012) (arguing based on experience with formulary apportionment among the states of the U.S. that disputes will continue on transfer pricing despite formulary apportionment).

${ }^{51}$ While the states of the U.S. use differing apportionment factors for business income, all include sales as a factor, and those using multiple factors use property and payroll as well. The CCCTB Proposal, supra note 37, apportions business income by equally weighted property, sales, and employment factors, but, in order to level the effect of wage differentials among member states, the employment factor is a combination of payroll and numbers of employees.
} 
jurisdictions in order to do so. If, as several commentators recommend, ${ }^{52}$ the GUGIT adopted a destination sales factor only apportionment formula, income shifting becomes impractical without loss of revenue. Preventing income shifting with a single destination sales factor disadvantages poorer countries as they tend to be producing but not consuming countries. Those producing countries might lose their tax base to consuming countries. ${ }^{53}$ In any event, an income distribution formula that is a function of real factors such as payroll, property and sales would make the decision to shift income less artificial than it is currently.

A GUGIT also would impact income shifting among members of enterprise groups insofar as the GUGIT consolidates the incomes of all members of an enterprise group. ${ }^{54}$ By eliminating intra-group transactions, the GUGIT restricts tax planning opportunities that rely on intra-group transfer prices. Formulary apportionment of income of the enterprise group's aggregate income replaces arms' length determinations of transfer prices. Payments from one group member to another, whether as sales, interest, dividends, or royalties similarly would not impact the distribution of income among jurisdictions. Instead the income would follow the apportionment factors of the group as a whole. Groups would be free to require intra group payments in order to redistribute the tax burden, but those payments would not impact the tax base distribution.

Since the distribution methodology renders it difficult to manipulate the geographic placement of income, tax competition might continue but would link closely to real investment in the taxing jurisdiction. When low-income countries deliver incentives to foreign direct investment with tax incentives, they no longer risk losing the intended effect of the benefit to the home country's credit-based foreign tax regime. Tax sparing treaty provisions become unnecessary to protect the low-income country's incentives. ${ }^{55}$ Yet, some leveling of tax rates is likely to follow. Countries losing investment may conform their rates more closely to countries gaining investment, so that cross-border competition becomes a function primarily of factors such as labor costs and direct subsidies rather tax rates. In its discussion of the CCCTB Proposal, the EP saw the harmonization of rates within a range as a natural complement to the CCCTB. ${ }^{56}$ In addition, higher tax jurisdictions may encourage or pressure lower tax jurisdictions to harmonize their rates with those of the higher tax jurisdictions, as high tax jurisdictions recently coerced tax havens to provide greater transparency, information reporting and other features necessary to prevent "harmful tax competition."

\footnotetext{
${ }^{52}$.Avi Yonah,. Clausing \&. Durst, Allocating Business Profits for Tax Purposes, supra note 3; Morse, Revisiting Formulary Apportionment, supra note 3.

${ }^{53}$ See discussion infra in Part 3.A.

${ }^{54}$ Defining the taxpayer for purposes of the GUGIT is likely to require analysis of the group members' community of interests. See discussion in part 3.B. infra.

${ }^{55}$ Kim Brooks, Tax Sparing: A Needed Incentive for Foreign Investment in Low-Income Countries or an Unnecessary Revenue Sacrifice?, 34 QUEEN’s L. J. 505 (2009) (arguing that tax sparing treaty provisions do not work efficiently and give rise to abuse).

56 The EP tends to view the next logical step harmonization of tax rates. See the further study recommendations of the EP action, supra note 38, Amendment 37 and the rapporteur's Explanatory Statement to accompany the EP enactment.

${ }^{57}$ OECD, HARMFUL TAX COMPETITION, supra note 8, (reporting on the features of harmful tax competition). OECD Bureau of Fiscal Affairs, Towards Global Tax Co-operation, REPORT TO THE 2000 MINISTERIAL COUNCIL MEETING AND RECOMMENDATIONS BY THE COMMITTEE ON FISCAL AFFAIRS, PROGRESS IN IDENTIFYING AND
} 
By limiting the value of subsidies through the tax system, the common tax base encourages jurisdictions to return to and increase use of transparent, direct subsidies. Public scrutiny of those direct subsidies brings the additional benefit of discouraging economically inefficient subsidies like those that the United States commonly has delivered through its income tax system. ${ }^{58}$

For most taxpayers, the GUGIT would change little from today. Although the rules of inclusion might differ from current rules, the bulk of taxpayers in any country do not engage in any cross-border activity or investing. Those taxpayers would report their incomes in much the same manner as they do today. For remaining taxpayers who or which engage in transactions or invest across national borders, the GUGIT diminishes compliance costs by requiring familiarity with and reporting under a single set of rules. ${ }^{59}$ The compliance cost savings ameliorates somewhat the negative cost that loss of flexibility in tax planning would entail, as might the diminution of deadweight loss accompanying reduced diversion of resources from business activity to tax planning and inefficient, but tax-advantaged, investment. ${ }^{60}$

Part 2. Centralization, Sovereignty, and Privacy. The GUGIT would have centralized reporting and auditing. This central global taxing authority just may be the most utopian of the GUGIT visions. ${ }^{61}$ The agency responsible for enforcement would be transnational. Each country would participate in the selection of the executives of the agency and assigning revenue

ELIMINATING HARMFUl TAX PRACTICES 16-26 (2000) (available at http://www.oecd.org/dataoecd/9/61/2090192.pdf) (identifying uncooperative tax haven jurisdictions and reporting on progress toward cooperation). Since 2009, the OECD no longer lists any country as an uncooperative tax haven. OECD Centre for Tax Policy and Administration, List of Unco-operative Tax Havens (available at http://www.oecd.org/document/57/0,3746,en_2649_33745_30578809_1_1_1_1,00.html, last visited June 27, 2012). ${ }^{58}$ I.R.C. §103, for example (exempting interest on state and local bonds). Marketing of tax exempt bonds often requires an interest rate greater than that which would attract the highest tax rate investors as bond purchasers. Since the rate is uniform on all bonds in an issue, the highest tax rate investor captures a higher than necessary rate when he purchases those bonds that have to be marketable to investors taxable at a lower rate thereby redirecting part of the subsidy intended to benefit the state or local governmental unit to the high rate investor.

${ }^{59}$ The EC estimated a 7 percent reduction in compliance costs for multi-national enterprises that selected the CCCTB. CCCTB Proposal, supra note 37, at 5.

${ }^{60}$ David M. Schizer, Sticks and Snakes: Derivatives and Curtailing Aggressive Tax Planning, 73 S.CAL. L. ReV. 1339, 1349 (2000) observing: "[i]f the taxsavings is less than the cost of changing behavior ("standard deadweight loss") and paying experts ("avoidance costs"), (footnote omitted) the issuer will use the more tax expensive form." And Klaus-Dieter Drüen, Unternehmerfreiheit und Steuerumgehung (Entrepreneurial Freedom and Tax Avoidance (author's translation)) 158, 2d column, STUW 2/2008, observes: “... Steuerumgehung volkswirtschaftlich betrachtet den Wett bewerb und führt zur ineffizienten Allokation von Ressourcen, weil beträchtliches Personal in Unternehmen, Steuerberatung und Staat fern von wirtschaftlicher Nutzenmaximierung gebunden wird." (citations omitted) ("from an economic perspective, tax avoidance disrupts competition and leads to inefficient allocation of resources as considerable personnel in business, tax planning industries, and the state is remains far from economic production maximization activity.) (author's translation).

${ }^{61}$ The agency would be gargantuan. At the end of 2011, the IRS had approximately 93,000 employees. INTERNAL REVENUE SERVICE DATA BOOK 2011 at 67. If the central taxing agency were the exclusive agency and employee numbers were to increase in proportion to the increase in the gross domestic product of the area administered, the agency would need perhaps one-half million employees. The US GDP in 2011 was approximately $\$ 15$ trillion, while world GDP was approximately \$75 trillion. Central Intelligence Agency, THE WORLD FACT BOOK (updated weekly online at https://www.cia.gov/library/publications/the-world-factbook/geos/xx.html. 
agents at all levels of the agency. The agency would have the authority to require both taxpayers and third parties to report information under uniform international standards. The GUGIT legislation similarly would require local courts to support the taxing authority's demand for information.

Most, possibly all, taxpayers would submit their tax data electronically under uniform electronic forms. The creation of identical forms in hundreds of languages is in and of itself a formidable task, but it is a task no different from that confronting current international bodies. ${ }^{62}$ Information submission would include data necessary to enable the central authority to distribute the taxpayer's income among the jurisdictions that would share the taxpayer's tax base.

Comprehensive third party information reporting and robust data matching would provide much of the information that the centralized agency would need to determine the tax base. Ideally, third parties would withhold and deposit part of any payment with the international tax agency. Where the nature of the income production activity is inconvenient for or precludes withholding, the taxpayer would have to make periodic estimated tax payments. The agency would retain the deposited funds in the currency deposited, but the taxpayer would have the minimal control over the funds to convert them into the taxpayer's currency of choice. ${ }^{63}$ With extensive withholding, national tax authorities would determine the amount of tax payable in their respective jurisdictions and recover all or part of the tax from withheld funds and estimated tax deposits. Withheld funds and estimated deposits are likely to be available to meet most tax obligations in the currency of the country requiring payment. Each country imposing a tax would receive payments from the taxpayer's withheld funds and estimated deposits first before looking to the taxpayer for payment.

Enhanced withholding and information reporting to facilitate the GUGIT may eliminate the need for many, perhaps most, taxpayers to self-report at all. Withholding and information reporting from third parties would provide both the information to determine the taxpayer's tax liability and the funds with which to pay the taxpayer's tax liability. ${ }^{64}$ Except in rare circumstances in which, for example, the taxpayer might claim non-income production related deductions other than a standard deduction, there would be little need to involve the taxpayer in that process. ${ }^{65}$

An organization sufficiently vast to administer taxation worldwide is likely to become unwieldy. Reliance on automated, non-discretionary operations with centralized data processing limits the need for discretionary administrative interventions that are the most cumbersome aspect of tax administration. Like any large administrative body, local or regional offices would

\footnotetext{
${ }^{62}$ See discussion in part 3.D. infra.

${ }^{63}$ A GUGIT is likely to stabilize currency conversion in many instances. See discussion in part 3.D. infra.

${ }^{64}$ In fact, the United States may be the outlier in requiring its taxpaying public to file returns of their income and assess their own tax. Many jurisdictions, Germany for example, require self-reporting and payment only from those taxpayers who receive substantial amounts of income from sources other than their salaries. Roman Seer,

BESTEUERUNGSVERFAHREN : RECHTSVERGLEICH USA-DEUTSCHLAND (Heidelberg 2002) (recommending selfassessment for Germany).

${ }^{65}$ Urban-Brookings Tax Policy Center, ThE TAX POLICY BRIEFING BoOK, Return Free Filing III-5-1 (2008) (using withholding and information reporting to eliminate filing for most taxpayers).
} 
have to carry out most day to day functions of tax administration that require direct taxpayer contact or the exercise of discretion. The challenge is enforcing worldwide uniformity and evenhandedness in tax administration. While the taxing authority would have to deal with taxpayers in their own languages so that local administration is essential to operating efficiency, preventing taxpayers from "gaming the system" by choosing one specific national taxing authority over others is indispensable to building public confidence. ${ }^{66}$ Underlying the EU's CCCTB is an implicit assumption that neither favoritism nor corruption is problematic in any EU member state. There the taxpayer continues to file and communicate primarily with its national taxing authority, and the local authority shares the information with the other jurisdictions in which the taxpayer operates. ${ }^{67}$ A global base does not lend itself as readily to similar no favoritism, no corruption assumptions. Since the perception of even-handed treatment of all taxpayers under a central and apolitical taxing authority encourages tax compliance, oversight centralization is a key feature of the GUGIT. In order to protect its legitimacy as an independent and multi-national administrative agency, it must manage interpretations and applications of rules as uniformly and impartially as the rules themselves. Centralization and independence of the agency controls the risk of local favoritism and corruption and overcomes the negative public perception that local authorities might favor local residents in application of the tax laws.

A functional central agency also must have the power to assemble tax information and coerce compliance without regard to national borders. Nations must be willing to cede their national sovereignty to instill the necessary administrative and enforcement powers in the agency and provide policing support of the agency's tax assessment and collection. While relinquishment of sovereignty historically has been a matter of coercion through military conquest, following World War II, limited surrenders of sovereignty for the purposes of maintaining peaceful relations and supporting trade and economic development across borders has become commonplace. Prime among those twentieth century compromises of national sovereignty is the formation of the $\mathrm{EU}^{68}$ in which the member states yielded autonomy, subject to the principles of subsidiarity ${ }^{69}$ and proportionality, ${ }^{70}$ in order to preserve peace in a region and capture the economic advantages of a common market for goods and services. ${ }^{71}$ Nevertheless,

\footnotetext{
${ }^{66}$ Local favoritism is a longstanding concern in the U.S. The effort to control favoritism underlies the constitutionally protected, diversity jurisdiction of the federal courts. U.S. Constitution Art III, Section 2.

${ }^{67}$ CCCTB Proposal, supra note 37, Article 109 at 58 (tax return filing with the principal tax authority where the group parent is resident).

68 The Treaty of Rome of March 25, 1957 (available at http://ec.europa.eu/economy_finance/emu_history/documents/treaties/rometreaty2.pdf) created the European Economic Community that ultimately became the EU. The Treaty of Rome emphasized the removal of trade barriers in order to stabilize the region.

69 "Under the principle of subsidiarity, in areas which do not fall within its exclusive competence, the Union shall act only if and in so far as the objectives of the proposed action cannot be sufficiently achieved by the Member States, either at central level or at regional and local level, but can rather, by reason of the scale or effects of the proposed action, be better achieved at Union level." Art. 5 3. of CONSOLIDATED VERSION OF THE TREATY ON EUROPEAN UNION, Official Journal of the European Union C 83/15 (30.3.2010) (available at http://eurlex.europa.eu/LexUriServ/LexUriServ.do?uri=OJ:C:2010:083:0013:0046:en:PDF).

70 "Under the principle of proportionality, the content and form of Union action shall not exceed what is necessary to achieve the objectives of the Treaties." Id. at Art. 54.

${ }^{71}$ For the first half of the twentieth century and much of the preceding centuries, one or another war plagued the European region and alliances constantly shifted. Despite the temporary loss of national sovereignty twice in the
} 
sovereignty often has proven a barrier to the creation of effective international agencies ${ }^{72}$ even though proliferation of international decision-making agencies acknowledges an ever increasing need for those bodies. ${ }^{73}$ Even the international agreement that introduced the common Euro currency in the EU protected national sovereignty on budgetary matters. ${ }^{74}$ That protection of sovereignty probably has contributed to the difficulties that the common currency is having in $2012-13^{75}$ and could result in the ultimate collapse of the currency union. ${ }^{76}$

Yielding sovereignty on tax matters may be easier than on matters of international borders, human rights, wealth distribution, control of the military, ${ }^{77}$ and prevention of war. Tax collection is indispensable to maintenance of governmental functions and the preservation of existing power concentrations. Technology and economic globalization has rendered it easier for taxpayers to shift revenue away from their home jurisdictions to diminish their tax burdens by way of transfer prices, by investments through bank secrecy jurisdictions using trusts, foundations, or local corporate entities, and by expatriation. Increased international cooperation on tax matters becomes increasingly important to protecting the tax base. Shortcomings in the effectiveness of international cooperation provide impetus for a GUGIT. Thus, while the EC's recent proposal on a CCCTB treads lightly on the issue of sovereignty, ${ }^{78}$ the EP's election to make the CCCTB mandatory is more realistic in its recognition that only mandatory tax harmonization will generate the needed predictability and commonality of taxation within the EU

twentieth century to Germany, member states submitted voluntarily to Germany's economic hegemony in order to build that market.

${ }^{72}$ The United Nations, for example, suffers from insufficient power to enforce actions of its body although "peacekeeping troops" under U.N. control do serve an important function in maintaining separation of hostile nations. The UN's primary authority comes in the form of unenforceable resolutions and agreements to cooperate voluntarily in matters such as Iran sanctions.

${ }^{73}$ In addition to the UN, there are regional organizations including the North Atlantic Treaty Organization, the Organization of American States, the Association of Southeast Asian Nations, worldwide financial organizations including the World Bank, Organization for Economic Cooperation and Development, the International Monetary Fund, the World Trade Association, and tribunals including the International Court of Justice and the International Court of Human Rights, all of which exercise governmental-like functions across national borders.

${ }^{74}$ Supra, note 7. For links to the various texts making up the The Stability and Growth Pact, see the EC's website for the legal texts at http://ec.europa.eu/economy_finance/economic_governance/sgp/legal_texts/index_en.htm. And see the more recent conclusions of the EC on maintaining growth and stability in the EU and protecting the Euro, EC, Conclusions - 28/29 June 2012 available at http://www.consilium.europa.eu/uedocs/cms_Data/docs/pressdata/en/ec/131388.pdf.

${ }^{75}$ International Monetary Fund, Global Financial Stability Report, Mounting Risks, Euro Area Worries Fuel Financial Instability (October 10, 2012) (available at http://www.imf.org/external/pubs/ft/survey/so/2012/new100912a.htm).

${ }^{76}$ Greece and Spain have called on the European Central Bank for assistance with their national debt. In Greece, serious political discussion of possible withdrawal from the euro currency and return to the Drachma ensued, but elections resulted in Greece's decision to remain in the currency union. See Rachel Donadio, Greek Voters Choose Party Supporting Bailout, NEW YORK TIMES A1 (June 18, 2012).

${ }^{77}$ With some regularity, nations even put their troops under the control of foreign military commanders through various alliances including NATO and UN peacekeeping missions.

${ }^{78}$ CCCTB Proposal, supra note 37, Explanatory Memorandum, Part 3 at 9-10 (addressing subsidiarity and proportionality in the context of voluntary participation in the CCCTB). 
and prevent taxpayers from choosing the CCCTB when it is beneficial to them but rejecting it when it is not. ${ }^{79}$

Since the OECD issued its initial report on harmful tax competition, ${ }^{80}$ there has been considerable and steady progress toward global tax information transparency. ${ }^{81}$ The Global Forum on Transparency and Exchange of Information for Tax Purposes (the Global Forum) currently has 118 member jurisdictions, ${ }^{82}$ including bank privacy jurisdictions such as Switzerland, Liechtenstein, ${ }^{83}$ and Luxembourg, plus the EU and nine observers. ${ }^{84}$ Among the observers are international fiscal institutions such as the World Bank, the International Monetary Fund, the Asian Development Bank, but the United Nations also is an observer. The Global Forum has conducted more than 79 peer reviews of various jurisdictions for transparency and exchange of tax information. ${ }^{85}$ The reviews have multiple stages. The 2012 report describes the review process:

The peer review process examines the legal and regulatory framework of member jurisdictions (Phase 1 reviews) and the actual implementation of the international standard of transparency and exchange of information in practice (Phase 2 reviews). The review outputs include determinations regarding the availability of any relevant information in tax matters (ownership, accounting or bank information), the appropriate power of the administration to access the information and the administration's capacity to deliver this information to any partner which requests it. ${ }^{86}$

Underlying the progress report is an assumption that tax transparency and exchange of information has become an internationally accepted objective. Members of the Global Forum strive to overcome internal barriers to transparency and exchange of information but no longer view transparency and exchange of information to be unacceptable compromise of national sovereignty. Needless to say, implementation of information sharing lags well behind execution of information sharing and transparency agreements. ${ }^{87}$ A recent (and politically charged report)

\footnotetext{
${ }^{79}$ EP, Legislative resolution of 19 April 2012 on the proposal for a Council directive on a Common Consolidated Corporate Tax Base (CCCTB), supra note 38.

${ }^{80}$ OECD, HARMFUL TAX COMPETITION, supra note 8.

${ }^{81}$ Or, from the information sharing opponents' perspective, considerable erosion of their privacy.

${ }^{82}$ OECD, The Global Forum on Tax Transparency welcomes Romania as new member (available at http://www.oecd.org/tax/transparency/theglobalforumontaxtransparencywelcomesromaniaasnewmember.htm).

${ }^{83}$ See, for example, Larry R. Kemm, William M. Sharp Sr., and William T. Harrison III, Liechtenstein and the U.S.: The Long Road to Full Disclosure, 67 TAX NOTES INT'L 355 (July 23, 2012) (discussing the TIEA between Liechtenstein and the U.S. and the change in Liechtenstein law expanding the scope of information available under TIEAs)

${ }^{84}$ Global Forum Progress Report, supra note 39, at 2 (at page 4, the report uses the number 108). The list of members appears in Annex III to the report at 25-6.

${ }^{85} I d$.

${ }^{86} \mathrm{Id}$. at 2. The report further refers to ten criteria of transparency and information exchange and lists them in Annex IV. at 27.

${ }^{87}$ Global Forum Progress Report, supra note 17, at 19-24 (Annex II especially column C5 assessing timeliness of exchange of information). Annex II displays in columnar form the results of the phase 1 assessments of transparency and exchange of information. The report does not display the results of the phase 2 implementation
} 
pegs the amount of net financial assets that wealthy individuals secrete in tax havens at 21 to 32 trillion dollars, yielding a loss in tax revenue of 190 to 280 billion dollars each year. ${ }^{88}$

Tax information exchange agreements (TIEAs) allow the taxing authorities in one country to access information that another country has collected or has the power to collect in the administration of its domestic tax laws. ${ }^{89}$ Information exchange agreements generally govern information concerning taxpayers and transactions that may impact the assessment and collection of taxes in second country but to which the second country lacks direct access. ${ }^{90}$ Need for the exchange may be a matter of a taxpayer failing to report information to a second country when the taxpayer is obliged to do so or may stem from the lack of the second country's jurisdiction over the record-keeper.

Sometimes the existence of a TIEA may make the task of securing taxpayer cooperation on disclosing financial and related information more difficult. Whenever one country may transfer information that individuals or entities must provide to another country, taxpayers and third party record-keepers raise concerns as to whether or not the requesting country will protect confidential information it receives through the exchange. ${ }^{91}$ Those concerns in some instances may be valid and the OECD model agreements seek to guarantee confidentiality of information. ${ }^{92}$ However, concerns also may stem from the taxpayers having sought to avoid or evade taxes in the country that is requesting the information. For those reasons, taxpayers may resist providing information voluntarily that they might have provided to the country having direct access to the taxpayer and record-keepers if the information were not subject to sharing. Practical concerns like those aside, national law has begun to yield to international law and treaties to give taxing agencies from one country authority to reach into another country for tax information. A country under appropriate TIEAs may collect information concerning its own residents and citizens and businesses having their base in that country with respect to financial and tax information from operations and activities in the country into which it is reaching. Many information exchange conventions require taxpayers to make information about themselves and third parties with whom they deal available to the foreign government's agencies. Yielding sovereignty becomes increasingly commonplace in the tax realm as information exchange

review but does observe that: "[ $\mathrm{t}]$ he main finding so far in several cases has been that information exchange is too slow and jurisdictions need to take steps to expedite the process." Id. at 15.

${ }^{88}$ William Hoffman, World's Wealthy Hide More Than \$20 Trillion in Offshore Havens, Study Says, 2012 TNT 142-5 (describing a report that the Tax Justice Network released). The report is: James S. Henry, The Price of Offshore Revisited: New Estimates for "Missing" Global Private Wealth, Income, Inequality, and Lost Taxes 5 (2012) (available at http://www.taxjustice.net/cms/upload/pdf/Price_of_Offshore_Revisited_120722.pdf) (estimating \$21-35 trillion in hidden private wealth).

${ }^{89}$ In 2002, the OECD Global Forum Working Group on Effective Exchange of Information developed bilateral and multilateral variants for a model TIEA to combat harmful tax competition by making it more difficult for taxpayers to hide assets and transactions in low tax jurisdictions. The model, Agreement on Exchange of Information on Tax Matters, is available at http://www.oecd.org/dataoecd/15/43/2082215.pdf.

${ }^{90} I d$.

${ }^{91}$ The U.S. provides statutory protection of taxpayer information under I.R.C. $\$ 6103$ prohibiting disclosure of returns and return information. I.R.C. $\$ 6103$ has an exception for disclosure of information for tax administration purposes, including "the administration, management, conduct, direction, and supervision of the execution and application ... tax conventions to which the United States is a party..." I.R.C. §6103(b)(4)(A)(i). I.R.C. $\$ 6103(\mathrm{k})(4)$ (permitting disclosure to foreign competent authority pursuant to treaty or convention).

${ }_{92}$ Article 8 of the OECD model, supra note 89 , protects the confidentiality of the exchanged information. 
agreements proliferate. ${ }^{93}$ Many countries have come to accept that sound international tax administration demands the relinquishment of sovereignty.

Given growing acceptance of transnational information sharing, it becomes easier to envision a GUGIT that a central and international authority administers. With a GUGIT, taxpayers' concerns about differing rules protecting confidential information become less cogent. Confidentiality protection rules are uniform throughout the GUGIT area. A central authority renders most historical competent authority functions obsolete and, accordingly, limits inquiry on matters that are internal to an enterprise, such as transfer pricing, since the GUGIT distributes the uniform tax base among the countries in which the taxpayer produces income. Risk of exposure of trade secrets often accompanies inquiry into the construction of the taxpayer's transfer price within an enterprise group. Taxpayers may continue to worry that enforcement of privacy protection will not be uniform, but the taxing authority's vital independence from the control of national governments ultimately should dispel those worries -- although not necessarily taxpayers' claims of concern.

Extensive third party reporting of information is an indispensable supporting pillar of a GUGIT. It simplifies data collection and verification. The arms' length relationship between the information provider and the taxpayer diminishes the likelihood of deception insofar as the third party has no incentive to risk civil and criminal penalties in order to protect an unrelated person's tax information. Certainly, the taxpayer could compensate the third party for withholding or falsifying information. Historically, tax professionals and financial institutions readily accepted compensation to withhold or even falsify information for taxpayers, ${ }^{94}$ but in light of broad based information reporting that must accompany the GUGIT, the risk of detection because yet another party must report the same transaction might deter such practices.

The GUGIT agency will have to overcome collateral concerns relating to personal privacy and protection of individual liberty. Between a taxpayer and the national tax collector, no country protects the individual's privacy. The tax collector has the authority to access all the taxpayer's business and personal records that relate in any way to the determination and assessment of tax. The taxpayer only has the right to protection from dissemination of private information beyond the tax collection agency and outside the scope of tax collection. The success of a GUGIT depends upon international recognition that the central taxing authority simply steps into the shoes and assumes all the authority of domestic taxing agencies. While it may be difficult to accept a foreigner asking questions about one's personal finances, most

\footnotetext{
${ }^{93}$ From 2008 through 2011, more than 800 TIEAs and dual tax conventions were signed. Each of those agreements requires some surrender of a nation's sovereign control over financial information of its residents or institutions and some level of international cooperation on tax reporting and collection. OECD, Global Forum on Transparency and Exchange of Information for Tax Purposes, Progress Report to the G20, supra note 39.

${ }^{94}$ Consider the role of professional advisors in tax shelter design, Ordower, Culture of Tax Avoidance, supra note 18 at 87-94, and the recent criminal conviction of tax shelter attorney Paul Daugerdas and others, Dept of Justice, Office of Public Affairs, Jenkens \& Gilchrist Attorneys, Former BDO Seidman CEO and Deutsche Bank Broker Found Guilty in New York of Multi-Billion Dollar Criminal Tax Fraud Scheme (May 24, 2011) (available at http://www.justice.gov/opa/pr/2011/May/11-tax-676.html). Daugerdas and Denis Field, however, have a new trial pending, while Donna Guerin pleaded guilty and will not have a new trial. Basil Katz, Ex-lawyer pleads guilty in tax case, avoids new trial (9/14/12) (available at http://newsandinsight.thomsonreuters.com/Legal/News/2012/09__September/Ex-lawyer_pleads_guilty_in_tax_case,_avoids_new_trial/). 
people readily relinquish information in order to cross national borders or engage in business activities outside their home countries. Athletes and entertainers frequently must address claims of foreign taxing authorities against a portion of their earnings. For those who do not cross national borders, or do so only for the purposes of tourism, their tax reporting and information disclosures will not differ significantly from what they do now. The agency to which they report may be different, but no country, other than their country of residence, will claim any portion of their taxes. Their personal information will be no more vulnerable than it is today. In fact, privacy protection is likely to be more vigilant under the GUGIT because the very size of the taxing authority makes security a primary structural concern.

Part 3. Some Technical Details of a GUGIT. A successful GUGIT design ${ }^{95}$ will limit opportunities for taxpayers to diminish their taxes through transaction structures that lack a compelling non-tax purpose. should be a matter of Economically sound choices independent of tax avoidance should determine business and investment decisions. ${ }^{96}$ The tax base involves at least four discrete design areas that the GUGIT project must and this article will address: A) the formula for distributing the tax base among jurisdictions in which the taxpayer is active, B) the definition of the taxpayer for purposes of the GUGIT, C) expatriation prevention, and D) language and currency translation. Part 4 addresses components of the base, including matters of accounting and specific inclusionary and exclusion rules.

A. The distribution formula. The CCCTB Proposal apportions business income among the jurisdictions in which the taxpayer is active according to a formula that gives equal weight to the three components of labor, property, and sales. ${ }^{97}$ The EP CCCTB resolution would decrease the sales factor to ten percent and increase each of the other factors to forty-five percent. ${ }^{98}$ Although the states of the United States use a combination of the property, payroll, and sales factors to apportion the income of corporations operating in more than one state, the states have not agreed on a single formula. ${ }^{99}$ Some states use only destination sales. ${ }^{100}$ In the course of collecting comments on the project, several commentators recommended to the CCCTB WG that destination sales should be the only factor because it is the most difficult factor to move from one taxing jurisdiction to another without the move impacting the profitability of

\footnotetext{
${ }^{95}$ Building consensus for a GUGIT will require long term gradual development that will include opportunities for all interested parties to participate. At best, this paper provides a point of departure for the discussion and does not aspire to completeness.

${ }^{96}$ Ordower, Culture of Tax Avoidance, supra note 18 at 70-72.-The CCCTB WG recognized the continuing risk of tax avoidance in the CCСТВ and included an anti-avoidance rule in the proposal. CCCTB Proposal Article 80, supra note 37 at 46.

${ }^{97}$ CCCTB Proposal, supra note 37, Art 86 at 49.

${ }^{98}$ Supra, note 38.

${ }^{99}$ While Article IV of the Multistate Tax Commission (MTC), Multistate Tax Compact (available on MTC's website at http://www.mtc.gov/About.aspx?id=86) uses an equally weighted three factor formula like that of the CCCTB Proposal. Only 18 states have adopted the Compact. MTC, Member States (available at http://www.mtc.gov/AboutStateMap.aspx). Other states use a variety of formulae, including 13 states that use only sales, some transitioning to only sales, other double or triple weighting of the sales factor. See, Federation of Tax Administrators, State Apportionment of Corporate Income, (Formulas for tax year 2012 -- as of January 1, 2012) (available at http://www.taxadmin.org/fta/rate/apport.pdf).

${ }^{100} I d$.

(C) Copyright 2013 Henry Ordower

Utopian GUGIT Visions 
the taxpayer negatively. ${ }^{101}$ In any event, support for formulary apportionment for multi-national corporations' international income is growing but not yet solid, ${ }^{102}$ and the apportionment formula is likely to include destination sales, property, and payroll.

1. The Sales Factor. Sales might be a reasonable choice as a single factor where the taxpayer is active only in countries having substantially equal tax rates and having populations with substantially equal abilities to consume. The EU might be just such a region, but, even there, significant differences in wage levels and the ability to consume inhere. The EP rapporteur attempted to "reconcile the various points of view about the factor "turnover," 103 by reducing the weighting of sales and increasing the weighting of the other factors. ${ }^{104}$ In the presence of large wealth disparities from country to country or region to region, destination sales is a far less compelling factor.

The sales factor apportions income to consuming countries even when production is in non-consuming countries. While it is difficult to manipulate the destination of sales without sacrificing profit, concentration of sales in wealthier jurisdictions deprives producing, but not consuming jurisdictions, of their shares of the tax base.

2. The Property Factor. Taxpayers locate their physical property where production or management activity takes place. Heavy industry, both manufacturing and extraction, use substantial amounts of physical property. While location of productive activity generally correlates with location of physical property, so that some labor-based measure of productive activity might substitute for that property in an apportionment formula, direct inclusion of a property factor in the apportionment formula seems appropriate.

Moreover, form of ownership should make no difference to formulary inclusion. Leased property should be part of the apportionment formula of the lessee during the term of its use of the property. While the payment of business rent would be a deductible expense under the GUGIT, the present value of the rental payments should constitute property for purposes of the allocation formula. The independence of the lessor from the lessee assures that the rental price reflects fair market rental value. Where the lessor and lessee are not dealing at arms' length, the GUGIT would disregard the lease and include the owned property as property of the taxpaying enterprise that includes both the lessor and the lessee. The property factor will apportion income to the location of the productive activity, whether the productive activity is the actual manufacturing or extraction or, in the case of management offices, the management of activity occurs.

\footnotetext{
${ }^{101}$ Reuven S.Avi Yonah, Kimberly A. Clausing \& Michael C. Durst, Allocating Business Profits, supra note 3, (relinquishing sales opportunities in order to move income to another jurisdiction hardly makes economic sense).

${ }^{102}$ Eric Kroh, Formulary Apportionment Could Resolve Problems With International Taxation System, Tax Notes Today (July 20, 2012) (available at http://services.taxanalysts.com/taxbase/tnt3.nsf/\%28Number/2012+TNT+1393? OpenDocument\&Login) (summarizing comments Lee Shepard of Tax Analysts and Paul Oosterhuis of Skadden, Arps, Slate, Meagher \& Flom LLP concerning formulary apportionment at an International Tax Institute forum). ${ }^{103}$ EP CCCTB resolutions, supra note 38.

${ }^{104} \mathrm{Id}$. Part of the objection lay in the universal presence in the EU of a destination sales based value added tax, so the proposed formula would give significant weight to sales under both primary tax systems in the EU, the income tax and the value added tax..
} 
To the contrary, the location of intangible property frequently bears little relationship to productive activity. Excluding intangible property from the apportionment formula prevents enterprises that generate income from intangible property from shifting the income artificially to lower tax jurisdictions. One may store the formula for a process or a pharmaceutical anywhere without adversely affecting the production from use of the intangible elsewhere. The CCCTB Proposal excludes intangible assets from the property factor of the apportionment formula because relocation of those assets requires no significant cost. ${ }^{105}$

Since the creation of the intangible property will manifest itself in the payroll factor during its creation and development and in the sales factor as it generates saleable goods or services, the GUGIT apportionment formula should disregard intangible property completely. Location of intangible intellectual property has been central to the aggressive use of transfer pricing to shift income to low tax jurisdictions. ${ }^{106}$ Similarly, other intangible property like goodwill follows the location of the enterprise headquarters and management. Several major corporations moved their nominal headquarters outside the United States ${ }^{107}$ in order to avoid the United States residual tax on income from lower tax jurisdictions. ${ }^{108}$ The costs associated with the headquarters' move generally were not significant and did not require top management to relocate to that jurisdiction. Those costs increased materially when the United States began to impose a continuing tax on the income of expatriate corporations. ${ }^{109}$ Disregarding intangibles in the property factor of the apportionment formula eliminates major complexities of the income tax and removes a principal incentive to establishing a presence in low tax jurisdictions to receive and own intellectual property and other intangible property.

3. The Payroll Factor. Outsourcing, whether contractual or by shifting one's own operations to a low wage and low cost jurisdiction, became common in the last decades of the twentieth century. Costs, not taxes, generally drove decisions to shift manufacturing, call centers, and other operations to those low cost jurisdictions, but one could envision taxes under an apportionment formula providing sufficient additional incentive to managers to relocate operations but not top management. ${ }^{110}$ A payroll factor that only takes gross wages (and,

${ }^{105}$ CCCTB Proposal, supra note 37, Article 921 . at 51.

${ }^{106}$ Intangibles have proven to be particularly problematic from a transfer pricing perspective. OECD, Transfer Pricing Aspects of Intangibles, supra note 25.

${ }^{107}$ The literature refers to the transaction as a corporate inversion. See, for example, Rachelle Y. Holmes, Deconstructing Corporate Tax, 25 AKRON TAX J. 1, 17-18 (discussing the reasons for corporate inversions). ${ }^{108}$ The inversion trend arose in part from the U.S.'s worldwide taxation of its citizens, permanent residents, and domestic corporations. The U.S. cedes primary taxing jurisdiction to the country in which the taxpayer earns income by giving the taxpayer a credit against the U.S. tax on that foreign income (but not exceeding the amount the U.S. tax would be on that income). I.R.C. $\$ 901$ (providing a tax credit for foreign taxes paid); I.R.C. §164(a) (3) (allowing a deduction for foreign taxes if the taxpayer does not elect a credit). Thus, a person subject to U.S. worldwide taxing jurisdictions pays tax at a combined rate no lower than the U.S. rate.

${ }^{109}$ I.R.C. $\$ 7874$ (imposing a tax on the income of a corporation that expatriates as if it continued to be a domestic corporation and taxing certain controlled expatriated corporations as domestic corporations). A number of countries that have a territorial system of taxation continue to impose a tax on the investment incomes of expatriates for a period as much as 10 years following expatriation. Inkomstskattlag (1999:1229) 3. Kap. $19 \S$ (Income Tax Law of Sweden 3. Chap. 19§) (taxing Swedish citizens and permanent residents who leave Sweden on income from capital). ${ }^{110}$ Kroh, Formulary Apportionment, supra note 102, (summarizing Oosterhuis' objections to formulary apportionment). 
presumably, also payments to independent contractors into account) may slant the weight of the factor to high wage jurisdictions where highly compensated managers are located or, in the case of development of intellectual property, including drugs, for example, the research and experimentation takes place. ${ }^{111}$ The CCCTB WG was mindful of wage differentials from country to country and tried to address the disparities by dividing the labor factor in its formula into two equally weighted components: payroll and number of employees. ${ }^{112}$ Rather than balancing wage differentials with an employee numbers feature, the formula could employ a cost of living or wage differential factor to adjust wages to a common value for purposes of applying the distribution formula. Alternatively, the formula could measure part of the payroll factor by taking person hours of work into account rather than a simple count of the number of employees since longer hours for low wages may characterize the working conditions in those outsourcing target jurisdictions.

4. The Beneficial Ownership Factor. While none of the existing apportionment formulae take underlying ownership into account, increasingly tax administrators probe beneficial ownership of entities in bank secrecy jurisdictions in order to determine whether taxpayers are concealing income on which they are subject to tax in the investigating jurisdiction. The United States long has required its taxpayers to report their investment accounts outside the United States. More recently, the IRS has begun to demand extensive information on beneficial ownership of accounts in Switzerland. Tax administrators in Germany and elsewhere in Europe purchased stolen secret bank records in order to identify German taxpayers who were using Liechtenstein foundations to avoid or evade taxes in Germany. ${ }^{113}$ The United States enacted legislation designed to ferret out additional information in order to tax United States citizens and residents on their offshore investment activities. ${ }^{114}$

With growing emphasis on beneficial ownership to prevent taxpayers from concealing assets and income, ${ }^{115}$ declining corporate tax rates, integration of corporate and shareholder taxes, and the increasing use of tax transparent entities, ${ }^{116}$ including a beneficial ownership factor in the apportionment formula would make sense. An entity's income inures directly through distributions and indirectly by way of capital appreciation to the entity's owners. Opponents of

\footnotetext{
${ }^{111}$ Short of intermediary entities such as personal service corporations established in low tax jurisdictions to provide the services of their otherwise highly compensated owner/employees, the labor portion of the formula is predominantly residence based.

${ }_{112}$ CCCTB Proposal, supra note 37, Art. 861 at 49.

${ }^{113}$ Gerson Trüg und Jörg Habetha, Die "Liechtensteiner Steueraffäre - Strafverfolgung durch Begehung von Straftaten? (The Liechtenstein Tax Matter - Criminal Pursuit through Commission of Criminal Offenses?), NEUE JURISTISCHE WOCHENSCHRIFT, 887 (2008) (describing the purchase of a CD rom with secret accountholder information for a price of some 4.2 million Euros).

${ }^{114}$ Congress enacted the Foreign Account Tax Compliance Act (FATCA) of 2010 as part of the Hiring Incentives to Restore Employment (HIRE) Act of 2010, PL 111-147 (3/18/10) (requiring taxpayers to report foreign financial holdings and foreign financial institutions to identify U.S. taxpayers among their direct and indirect accountholders; imposing penalties for failure to comply with reporting requirements).

${ }^{115}$ See, for example, OECD Model TIEA, supra note 89, Article 5 Exchange of Information on Request emphasizes in various places identification of beneficial rather than legal ownership as a criterion for exchange.

${ }^{116}$ Partnerships (including limited liability companies in the United States) and limited partnerships, and trusts in common law jurisdictions generally are transparent so that the income of the entity is taxable to the owners of the entity and not to the entity itself.
} 
the corporate income tax often characterize tax on corporate distributions following a tax on the corporate income as double taxation. In identifying where income should be taxed, a beneficial ownership factor in the formula directs the income to where it provides its final economic benefit.

One even might argue that income should be taxable only where the benefit accrues so that the single factor of beneficial ownership should be the only apportionment factor. Applying a single factor beneficial ownership formula concentrates income in wealthy jurisdictions even if sales and production occur in less wealthy jurisdictions. Accordingly, beneficial ownership of income (or the income producing entity) should be one of the several apportionment factors but probably should not be the only factor in the distribution formula.

Requiring identification of the underlying ownership, subject to protection of the identity of the owners where they desire that protection, should not be a barrier to that apportionment factor. Use of beneficial ownership as a factor also might lead to simplification of unnecessarily complex entity structures when the owners no longer may hide behind layers of entities.

Moreover, technology for tracking changes in ownership is readily available to enable entities to identify actual ownership and changes in ownership on a daily basis. The statutes would require beneficial ownership disclosure to the entity in order to enable it to comply with its statutory obligation to apply the apportionment formula.

Supported by robust anti-avoidance provisions, apportionment of business income under a formula composed of sales, property, payroll, and beneficial ownership would strike a sound and fair balance for income distribution of enterprises. Sales and beneficial ownership would tend, although not identically, to place income in wealthier consuming countries while property and payroll would apportion income to producing and manufacturing countries. The bifurcated payroll factor of employee numbers, work hours, or adjusted wages for cost of living differentials would balance in part the high wages in the formula that favor top management in the wealthier countries. Similarly, the property factor could use an adjustment factor to eliminate the distortion that very low and very high cost locations bring to the formula. Investment (capital) income of operating enterprises would follow income from production under an assumption that investment return is a function of the underlying income production and accompanying retention and investment.

For investment entities not part of a larger enterprise engaged in the active conduct of business, income should follow a single factor of beneficial ownership except where the investment is inextricably linked to specific countries. Income from direct investment in real property, natural resources, and personal property used in a specific country and the investment return from a pooled investment vehicle that invests in such property ${ }^{117}$ probably should be taxable in the country of permanent location, extraction, or use.

\footnotetext{
${ }^{117}$ Especially if it is tax transparent like a REIT, for example. 
5. Individuals. To this point the discussion has focused on enterprises composed of any combination of entities (or a single entity) and individual sole proprietorships ${ }^{118}$ having property, payroll, sales of goods or services, or beneficial ownership in more than one jurisdiction. A comprehensive GUGIT addresses taxation of individuals as well and contemplates a uniform set of rules that determine the tax base that includes income from individuals' services and from their investments. As noted above, ${ }^{119}$ while the GUGIT may alter specific rules of inclusion, exclusion, or deduction in the course of harmonizing those rules worldwide, the changes may appear no different from tax law changes that national legislatures make regularly. The GUGIT will change little else for most individuals, as it will allocate income from services an individual performs in the single jurisdiction where the individual lives and works to that jurisdiction. Similarly, investment income from domestic financial accounts and stocks will be taxable in the jurisdiction in which the individual lives and works. Such individuals will continue to report income locally and deal with local tax offices if necessary. In the presence of extensive third party information reporting and withholding, ${ }^{120}$ self-reporting and self-assessment will become obsolete.

This section suggests several models for apportionment of income from services so that individuals, who work in more than one jurisdiction or work in a jurisdiction different from that in which they live, may find the GUGIT affecting them more profoundly. One model, however, may require no major changes from the taxation of individuals under current double tax convention practice. Consistent with the OECD's Model Tax Convention, ${ }^{121}$ under many double taxation treaties, countries in which a nonresident works often cede the authority to tax income from services under the countries' general income tax, but not under wage taxes for retirement and insurance programs, ${ }^{122}$ to the jurisdiction in which the individual resides. ${ }^{123}$ Exceptions to this cession of taxing power under the treaties exist for certain types of services, including

\footnotetext{
118 The OECD Model Tax Convention on Income and on Capital (Condensed Version) (2010) (available at http://www.keepeek.com/Digital-Asset-Management/oecd/taxation/model-tax-convention-on-income-and-oncapital-condensed-version-2010_mtc_cond-2010-en) (OECD Model Convention in the following) deleted Article 14 Independent Personal Services in the year 2000 because of overlap with Article 7 Business Profits, so that Article 14 was unnecessary. Commentary on Article 14, id., at 250. Independent personal services constitute a trade of business so that income from that trade or business is Article 7 Business Profits (allocating business profits to the residence jurisdiction unless the taxpayer produces the profits from a permanent establishment in the other country subject to an embedded transfer pricing rule).

119 Text following note 58 supra.

${ }^{120}$ See supra note 65 and accompanying text.

121 Supra note 118.

${ }^{122}$ OECD Model Convention, supra note 118, Article 2 Taxes Covered. Compare Article 2 of the Convention between the United States of America and the Federal Republic of Germany for the Avoidance of Double Taxation and the Prevention of Fiscal Evasion with respect to Taxes on Income and Capital and to Certain Other Taxes (1989) (available at http://www.irs.gov/pub/irs-trty/germany.pdf ) (Germany - US Double Tax Treaty).

${ }^{123}$ For example, see Article 7 Business Profits and Article 14 Independent Personal Services (repealed in the OECD Model Convention, supra note 118, favoring the jurisdiction of residence unless the taxpayer works from a fixed place in the other country) and Article 15 Dependent Personal Services (favoring the residence jurisdiction but permitting the other country to tax income from services performed there if the taxpayer is not present in her resident jurisdiction more than half the year) of the Germany - US Double Tax Treaty, supra note 122. Likewise, OECD Model Convention, supra note 118, Article 15 Dependent Personal Services at 31 (favoring resident jurisdiction unless taxpayer works in the other country and is not present in resident country more than half the year).
}

(C) Copyright 2013 Henry Ordower

Utopian GUGIT Visions 
athletic and entertainment activities, which are taxable in both the resident country and the country in which the individual engages in the activity. ${ }^{124}$ Other than those exceptions, only when the individual does not live most of the year in her country of residence, do the treaties give the jurisdiction in which the individual performs services as an employee the authority to tax the individual's wages. ${ }^{125}$ In those instances, jurisdictions with territorial tax systems cede the authority to tax the taxpayer's income from personal services to the jurisdiction in which the individual performs services. ${ }^{126}$ And when the taxpayer performs services as an independent contractor and not an employee from a permanent establishment may the work location tax the service provider. $^{127}$

Under its global income taxation system, ${ }^{128}$ however, the United States continues to tax even if the individual properly becomes taxable on her wages in another country. To prevent double taxation of the income, the United States applies any properly imposed foreign income taxes as a credit against the United States income tax otherwise payable. ${ }^{129}$ The income from services of a United States citizen or permanent resident will be subject to a tax rate lower than the United States' tax rate on that income only when the individual qualifies for the limited exclusion for United States persons who live and work outside the United States. ${ }^{130}$ Otherwise the individual is taxable in the United States on the foreign earned income, and all United States individuals also are taxable on their foreign earned income in excess of the limitation. ${ }^{131}$ Foreign taxes payable on the income from services are creditable in the United States but not to the extent the foreign taxes exceed the United States income tax on that income. ${ }^{132}$

The residence-based allocation rule of modern treaties has much to recommend it for the GUGIT. The rule is simple to apply. A residence rule enables most taxpayers to participate in a single country's array of social welfare programs and retirement systems. Choice of one's place of residence under a more than half year rule would seem a sufficiently important personal decision that for most taxpayers the decision remains free from tax planning motivations. ${ }^{133}$ Nevertheless, expatriation to avoid taxes remains a recurrent theme in the United States ${ }^{134}$ and

\footnotetext{
${ }^{124}$ Id. Article 17.

${ }^{125}$ Id. Article 15.

${ }^{126}$ Sweden, for example, exempts its citizens and residents from Swedish income tax if they reside and work outside Sweden for at least six months and are taxable on the personal services income in the other country, and, without regard to taxation in the country where they work if the period is at least one year. Inkomstskattelag (Sweden), supra note 109, 3. Kap. 9 §.

${ }^{127}$ OECD Model Convention, supra note 118, Article 7 Business Profits.

${ }^{128}$ I.R.C. $\$ 61$ (including in the individual's gross income "all income from whatever source derived" without regard to where the individual earns the income).

${ }^{129}$ I.R.C. $\$ 901$.

${ }^{130}$ I.R.C. $\$ 911$ (excluding an inflation adjusted amount of income in the case of U.S. citizens who are bona fide foreign resident living outside the U.S. for the full tax year or U.S. citizens or residents residing outside the U.S. 330 days in any 12 month period).

${ }^{131}$ I.R.C. $\$ 61$.

${ }^{132}$ I.R.C. $\$ 901$ (providing a credit for foreign taxes); I.R.C. $\$ 904$ (limiting the credit under I.R.C. $\$ 901$ to a proportional amount of the U.S. tax on the foreign income).

${ }^{133}$ Compare, doctrine of acts of independent significance referring to acts that are unlikely to be within a taxpayer's control or which the taxpayer is unlikely to engage in for tax avoidance purposes.

${ }^{134}$ Marie Sapirie, Facebook Expat Is Latest Billionaire Without Borders, 2012 WTD 96-3 (discussing expatriation to avoid U.S. taxes). For a list of $1^{\text {st }}$ quarter 2012 expatriates (including long term, non-citizens who relinquished
} 
other countries and may require anti-avoidance rules to prevent taxpayers from changing primary residence without relinquishing the collateral characteristics of their previous residence. ${ }^{135}$

Other configurations of the allocation rule might make expatriation less dependent upon an anti-avoidance rules and might distribute revenue more equitably among the states in which the taxpayer is active. A residence-based rule also is problematic because it is likely to result in considerable mismatching of income and deduction whenever the service recipient is taxable in one country and the service provider taxable in another.

Treaties recognize that for certain taxpayers the performance jurisdiction should have the right to tax the income. ${ }^{136}$ Determining how much of the taxpayer's income is attributable to the place of performance may be no easy matter. For example, an athlete may train in one country, perhaps the country of her residence, but receive payment for competing in another. If the athlete would receive no payment without a successful outcome, place of performance arguably is the place of the competition only, even if the time the athlete spends there is small relative to the time in training. On the other hand, without the training, the athlete would be unlikely to compete successfully so the income belongs primarily to the place of training. An athlete who receives a salary from an employer based in the country where she trains but who competes in another country should be taxable in both. Allocation might follow an absolute measure of time spent in each location, the measure of time that the athlete engages in the athletic activity in each jurisdiction, both training and competition, or perhaps heavier weighting of the time in competition in an allocation based on the proportional amount of weighted time she devotes to the athletic activity in each. ${ }^{137}$ The issues for entertainers are the same. In both the case of the athlete and the entertainer, the individual is selling into and performing some part of her services in a jurisdiction in which she does not reside. With or without a GUGIT, the issue of place of performance often is ambiguous.

Even more perplexing is where to allocate the service income of an individual who performs services remotely from a fixed location for customers located in other jurisdictions. By analogy to destination sales-based apportionment, ${ }^{138}$ it might be appropriate to tax the services where the customer receives delivery and consumes them rather than where the service provider performs them. For example, a customer might commission an $\operatorname{artist}^{139}$ who lives and works in country A to create artwork for the customer's office building in country B. Simplifying the issue, assume the artist never enters country B, and the customer sends a representative to country A to collect the completed work and transport it to country B. Should the result differ if

\footnotetext{
permanent residency) see Department of the Treasury, Internal Revenue Service, Quarterly Publication of Individuals, Who Have Chosen To Expatriate, 77 F.R. 25538-44 (April 30, 2012).

${ }^{135}$ See discussion infra in part 3.C.

${ }^{136}$ OECD Model Convention, supra note 118, Article 17 Artistes and Sportsmen (allowing the country of performance to tax).

${ }^{137}$ Compare OECD Model Convention, supra note 118, Commentary to Article 17 (not providing a method for determining what portion of the athlete's or entertainer's income is attributable to the place of performance).

${ }^{138}$ See discussion supra note 101 and accompanying text.

${ }^{139}$ Implicit in the commentary to Article 17 of the OECD Model Convention, supra note 118 at 271 is that the term "artiste" does not contemplate a sculptor or painter but may include a performance artist because of the performance element of the art.
} 
the artist ships the completed work to customer in country B, or the artist makes a single trip to B in order to oversee the installation of the work? ${ }^{140}$ Remote performance of technology services is still more bewildering. With technology services, a technician in country A, all of whose clients are in country B, may reach into country B through cyberspace in order to alter, create, repair, or destroy an item that the customer or target uses in country B or elsewhere and which may have no physical manifestation at all. The data may be stored in country B or anywhere else in the world, including a satellite or under an arctic or Antarctic ice sheet.

Yet, a residence rule that would allocate all a taxpayer's service income to the single jurisdiction in which the taxpayer resides without regard to the identity of the employer or other payer is somewhat unsatisfying. The rule might be better if, for a taxpayer who regularly splits her residence time between or among jurisdictions, the rule would allocate all income from services according to those relative periods of time. Temporary presence and work in another jurisdiction for an aggregate period during the year that does not exceed a minimal period, ten days, for example, the rule would disregard. For most taxpayers, the rule corresponds to their activities and simplifies reporting for them when they spend short periods in another jurisdiction. For the athletes and artists, in the example above, a special rule of allocation still might be necessary if the principal source of income for the taxpayer were a competition or two in a country where the taxpayer spends little time.

A payer rule, on the other hand, would allocate the income to the country in which the payer takes the expenditure into account, whether by way of deduction or capitalization. A payer rule is appealing because it avoids mismatching of income and deduction. For each deduction, there is an inclusion in the same country. A payer rule may provide the fewest opportunities for tax planning since the business decision that drives the employment places the payer and the recipient at arms' length to one another. A payer rule, however, may complicate reporting for the individual service provider and subject her to taxation in other countries even if she does not perform any services in those countries. ${ }^{141}$ While the mechanics of a single tax administrative agency may simplify the reporting, the outcome may seem unfair to a taxpayer who does not leave her residence jurisdiction to perform services but works for a foreign employer. The taxpayer even may be unaware that the employer is foreign. ${ }^{142}$

Finally, rather than a place of performance rule, a rule that allocates income based upon the intended impact of the performance of services would allocate income to the jurisdiction where the individual's services have their impact. While athletes might be taxable under that rule only where they compete and not where they train, in most cases their performance would carry recognition and intended impact through endorsements, for example, in their home country as well as the performance country. Remote services are taxable not at the location of the

\footnotetext{
${ }^{140}$ The CCCTB Proposal, supra note 37, Article 96 at 52-3 (using destination sales as the sales factor but having alternative rules to deal with the complexity of the issue for goods and especially services). On the other hand, for the labor factor in the apportionment formula, an employee is allocated to the member of the enterprise group from which the employee receives payment. Id. , Article 91 1. at 50.

${ }^{141}$ Compare the CCCTB Proposal, supra note 37, Art. 91 1. at 50 (including employees in the labor factor of the group member from whom they receive compensation).

${ }_{142}$ Id. Art 91 2. (including employees in the labor factor of a group member for which they work if different from the payer).
} 
taxpayer and but where those services have their intended impact. Such an impact rule is also likely to allocate a larger proportional share of the income of highly compensated individuals to poorer countries where those individuals may be responsible for the business decisions concerning operations and activities in those countries including manufacturing and natural resource production. This impact rule might distribute taxable income more fairly between rich and poor countries although a modified residence rule might accomplish the same end as top managers are likely to visit facilities in poorer countries regularly even if the managers are not based in those countries. Problems of mismatching income and deduction might inhere under such a rule, but, in many cases, the distribution formula for business income would apportion more of the income to the producing countries so that the impact rule would match the income and deduction. Undoubtedly, an impact rule would be at least somewhat unwieldy as place of impact is likely to be uncertain in many instances and in others services may have an intended impact in multiple jurisdictions.

6. Investment Income. An individual's income from investment raises questions different from her income from personal services. Most investments do not have a place of performance and often do not present any risk of mismatching inclusion of income and deduction of payment in so far as investment gains, as opposed to periodic payments of interest, dividend, or royalty, give rise to no deduction. Under current law, an individual taxpayer is taxable in her country of residence and on periodic payments frequently also is taxable in the country of the investment as well. ${ }^{143}$ Since the taxpayer may have no other contact with the investment jurisdiction, withholding taxes at the source of the payment of an investment return substitute for tax returns for the foreign investors. ${ }^{144}$ Treaties frequently reduce the rate or eliminate the withholding tax and cede the jurisdiction to tax to the investor's home country. ${ }^{145}$ Subject to tax avoidance expatriation rules, ${ }^{146}$ countries with territorial income tax systems do not tax their citizens who live abroad on investment income even if they retain their citizenship. ${ }^{147}$ The United States differs in this respect as well by conditioning exemption from United States income taxes on relinquishment of citizenship. ${ }^{148}$

Investment income in the case of an enterprise derives from the investment of retained revenue. Apportioning the investment income in the same manner as the active income of the enterprise approximates attributing the investment income to the source of the funds for investment. Investment income for individuals similarly might follow the allocation of the

\footnotetext{
${ }^{143}$ Art. 10 Dividends and Art. 11 Interest (taxable in country of residence but also by limited withholding tax in country of source), OECD Model Convention, supra, note 123, but not Art. 12 Royalties (taxable only in residence country unless from a permanent establishment in the source country).

${ }^{144}$ I.R.C. $\$ \S 871$ and 881 (providing a withholding tax on periodic income on non-resident individuals and corporations respectively) are representative of withholding at the source.

${ }^{145}$ U.S. - Germany Double Tax Convention, supra note 123, Article 10 (reducing the withholding rate on dividends from 30 percent (I.R.C. §871) to 5 or 15 percent), Articles 11 and 12 (empowering only the country of residence to tax interest and royalties respectively).

${ }^{146}$ Sweden, for example, supra, note 109. See part 3.C. infra.

${ }^{147}$ Individuals resident in or having certain connections to and previously resident Sweden are taxable on their income from all sources in Sweden. Inkomstskattelag (Sweden), supra note 109, 3. Kap. 3 §. Non-residents, whether or not Swedish citizens, are taxable only on income from Swedish sources. Id. 3. Kap. 18 §.

${ }^{148}$ Treas. reg. § 1.1-1(a) (imposing "an income tax on the income of every individual who is a citizen or resident of the United States...). I.R.C. §61 (including all income from whatever source derived in gross income). 
individual's personal service income as the source of funds for the individual to invest. Such a rule is far less compelling for individuals than it is for enterprises. After retirement, for example, the individual no longer would have service income to follow although the formula might take the individual's lifelong work record or, in order to simplify the process, an average of some number of years of the individual's work record into account and allocate investment income according to that determination. That generalization, however, fails to account for the wealth many individuals inherit or receive as gifts. To be consistent with the production rule for the investment income from that wealth, one would have to look to the donor's work history rather than the donee's whose taxes are at issue. That might prove a formidable task over several generations of gifts.

Principal residence-based allocation, subject to a few special rules for investments in tangible productive property ${ }^{149}$ having a direct geographical link to a specific country, including rental personal and real property, natural resource production, farming properties, might work more smoothly than allocation following service income. It is a less appealing rule when an individual lives in one country but works in a neighboring country or when an individual stops working and moves to another country from that in which she worked, thereby depriving the country in which she earned her wealth of the tax on the income from the investment of that earned wealth. In the latter case, investment income should be taxable in the jurisdiction of residence but subject to expatriation limitations. ${ }^{150}$ In the former instance, even though a portion or all the investment income results from investment of the income from the individual's services in another jurisdiction, simplicity and adherence to existing prevailing rules should take precedence. In any event, if the trend of preferential rates of tax on capital income continues, taxing investment income that is not part of a trade or business but primarily capital income may represent a smaller loss of revenue than loss of the tax on income from personal services.

B. Enterprise and related taxpayer definitions. Most income tax systems examine transactions between related taxpayers under various arms' length pricing standards. Rules that permit the tax collector to adjust the price for tax purposes between such taxpayers to an appropriate arms' length price ${ }^{151}$ without regard to actual payment amounts ${ }^{152}$ recognize that taxpayers may not set their prices at arms' length because of their close relationship. Even when the price may be arms' length, the allocation of asset ownership among members of a taxpayer's interest group may shift income from that asset to low tax jurisdictions artificially. Chief among the assets that taxpayers have used within a group to shift income has been intangible property, especially intellectual property. By shifting ownership to a related entity in a low tax offshore jurisdiction, the domestic taxpayer that may own the offshore group member defers domestic taxes until they repatriate the income from the offshore group member in those jurisdictions that

\footnotetext{
${ }^{149}$ In many instances, the U.S. tax law might view such investments as income from the conduct of a trade or business as opposed to investment income.

${ }^{150}$ See part 3.C. infra.

${ }^{151}$ I.R.C. $\$ 482$, for example (giving the IRS the power to redetermine prices in transactions between related taxpayers).

${ }^{152}$ The tax collector may not require the taxpayers to change their actual prices but may require taxpayers to determine income and deduction based upon an adjusted price.
} 
tax domestic persons on their worldwide income ${ }^{153}$ and may eliminate domestic taxation of the income where the jurisdiction only taxes domestic persons on their income from domestic sources and not on distributions from foreign group members.

Even when pricing is correct, taxpayers may manipulate the timing of income or loss under a realization based tax system without relinquishing interest group control of the property. Statutory rules in the United States, for example, deter some timing shifts by denying losses on sales between related taxpayers. ${ }^{154}$ Under the GUGIT's concept of taxpayer group, timing of inclusion and deduction would correspond in most instances with the group's actual relinquishment of ownership or control of the asset sold.

Essential to limiting taxpayers' opportunities to shift income to low tax jurisdictions under the GUGIT is a robust mechanism that apportions a single tax base among taxpayers who or which act or tend to act in concert. Determining which taxpayers are sufficiently closely related to share a common tax base informs two basic issues: (i) income splitting to shift income to a taxpayer subject to a lower rate of tax in the same or another taxing jurisdiction and (ii) the privilege to use losses from one person to offset another person's income. While these issues frequently manifest themselves in enterprise groups, tax administrators have struggled with them in family settings as well. For example, the United States Supreme Court determined that one spouse may not shift income from his personal services contractually to the other spouse even though the binding contractual obligation arose before the taxpayer performed the services and gave the other spouse the legal right to that income. ${ }^{155}$ The United States ultimately resolved the marital unit issue by permitting spouses to file a joint return of income. The issue inheres for non-marital relationships.

Despite the Court decisions barring direct shifting of income from services, opportunities to shift income indirectly abide. A taxpayer may interpose an entity, including a tax transparent entity like a partnership, S corporation, or limited liability company, and perform services on behalf of the entity. The service provider effectively shifts income to the entity in exchange for a smaller amount of compensation from the entity and shares the income with other owners who might be related to the service provider. Taxpayers also may shift income from services by transforming their services into property. Painters, composers, builders, for examples, shift income by giving the finished product to a family member who sells the product and includes the taxable income from the sale. Tax rules often combat artificial shifts of income with anti-

\footnotetext{
${ }^{153}$ The U.S., for example, see treas. reg. §1.1-1(a) (taxing resident and nonresident U.S. citizens on their worldwide incomes).

${ }^{154}$ For example, I.R.C. $\$ 267$ (disallowing the deduction of losses on sales of property between related taxpayers).

${ }^{155}$ Lucas v. Earl, 281 U.S. 111 (1930) (holding that a binding contract between spouses under which the working spouse assigns half his income from services to the other spouse does not prevent the working spouse from having to include the full amount of his service income for tax purposes). However, if the assignment of income is by operation of law in a community property jurisdiction, the working spouse is taxed on only half the income. Poe v. Seaborn, 282 U.S. 101 (1930). Community property laws applicable to married individuals split income between spouses so that each spouse is entitled to one-half the income of the marital unit. There is a considerable body of commentary on the interplay between the community property laws in California as applicable to those same sex couples who married before the California referendum ended same sex marriage and the Defense of Marriage Act's rejection for federal purposes of same sex marriage.
} 
avoidance rules. In the United States, several statutes allow the IRS to reallocate income among related taxpayers to prevent tax avoidance. ${ }^{156}$

Income splitting includes a wide-range of permutations. As noted above, ${ }^{157}$ for enterprise groups, the problem in the international context takes the form of transfer pricing ${ }^{158}$ and placement of ownership of intangible assets in low tax countries. If the related taxpayers together are a single taxpayer under a GUGIT, the GUGIT's formula for distribution of the tax base disregards transactions between members of the single taxpayer group, so that the transfer price would be of no concern for tax purposes. A major source of contention between taxpayers and their national tax collectors would disappear with transfer pricing. ${ }^{159}$ And the GUGIT apportions the group income without regard to the location of intangible assets, so that positioning those assets in low tax jurisdictions does not shift the income from those assets to that jurisdiction. ${ }^{160}$

With respect to enterprise groups, the CCCTB Proposal identifies the taxpayer by means of dual test of ownership and voting control. It requires ownership of more than fifty percent voting rights and more than seventy-five percent equity for consolidation. ${ }^{161}$ The United States always has used a much higher common ownership rule in permitting domestic corporations to become a single taxpayer. Domestic corporations ${ }^{162}$ in the United States may consolidate their returns under an affiliated group concept of eighty percent or more common control and ownership. The consolidated return statute precludes foreign corporations from consolidating with domestic corporations. ${ }^{163}$ Subject to limitations that prevent taxpayers from trafficking in carryovers of losses ${ }^{164}$ consolidation enables the consolidated taxpayer to offset income from one member of the group with losses from another member of the group. Under CCCTB consolidation, but not United States consolidation because transfer pricing is a cross-border concern and the United States does not permit foreign corporations to consolidate with domestic corporations, the consolidation eliminates those intra group transactions that generate transfer pricing concerns.

\footnotetext{
${ }^{156}$ I.R.C. $\$ 482$ (permitting the IRS to reallocate tax items among taxpayers in order to prevent tax avoidance). I.R.C. $\$ 704(\mathrm{e})$ (reallocating income in family partnerships to prevent understatement of income to the service provider).

${ }^{157}$ Supra note 151 and accompanying text.

${ }^{158}$ OECD, discussion draft on the Transfer Pricing Aspects of Intangibles, supra note 25.

${ }^{159}$ Presumably the transfer pricing issue is only a related taxpayer problem. Unrelated taxpayers are likely to set prices that do not result in artificial shifting of income from one taxpayer to another in order to exploit lower tax rates for one taxpayer although in instances in which rates of tax differ with the type of income for one taxpayer but not the other, even unrelated taxpayers may try to shift income types to arbitrage the rate differentials. I.R.C. $\S 704(\mathrm{c})$ recognizes this unrelated taxpayer problem and prohibits the shifting of gain and loss on contributed property among partners in a partnership by taxing built-in gains and losses to the contributing partner when the partnership disposes of the contributed property.

${ }^{160}$ See discussion of intangible property in the apportionment formula supra in part 3.A.2.

${ }^{161}$ CCCTB Proposal, supra note 37, at 13.

${ }^{162}$ I.R.C. $\$ 1501$ (permitting affiliated groups to file consolidated return); I.R.C. $\$ 1504$ (defining includible corporation in an affiliated group as 80 percent voting and value).

${ }^{163}$ I.R.C. $\S 1504(\mathrm{~b})(3)$ (excluding foreign corporations from the definition of includible corporation).

${ }^{164}$ I.R.C. $\$ \S 382,383$ (b), for example, that limit deductibility of net operating losses and capital losses on change of ownership of a corporation.
} 
Both the United States consolidated return rules and the CCCTB Proposal address only entity groups but a GUGIT should include a common enterprise concept for individuals and entities and individuals together as well as entities. In the United States, only in the cases of married individuals, ${ }^{165}$ where joint tax filing may be beneficial, and minors and their parents, ${ }^{166}$ where the community would suffer the tax detriment of a higher rate, do the taxable income, tax rates, and losses of one individual impact the taxable income, tax rates, and losses of any other individual expressly. Nevertheless, many other communities of interest among individuals exist, including cohabiting, but unmarried, individuals, some related, some unrelated, who may share expenses and income, but the Code does not take them into account. Taxpayers in the United States may elect to split income and deductions of various types through a variety of tax transparent or semi-transparent entities when splitting may be beneficial to them and avoid tax transparency when splitting might be detrimental. Other provisions prevent members of a family from deducting losses on sales of property from certain family members to others, ${ }^{167}$ but those provisions do not encompass other communities of interest and other transactions. The GUGIT may afford the opportunity to revisit those underlying tax law assumptions about relationships and define the community in a broader and possibly more contemporary manner including cohabitation, income and expense sharing, common economic plans and goals, or even acting in concert as the securities laws view shareholder groups, ${ }^{168}$ for examples.

While a high common ownership threshold might prevent taxpayers from using the GUGIT to their advantage, ${ }^{169}$ the high threshold also limits the GUGIT's ability to prevent taxpayers' manipulation of transactions within a non-consolidated interest group. In the United States it is more difficult for taxpayers to elect to combine as a single taxpayer than it is for the taxing agency to combine taxpayers in order to disregard transactions or structures that are beneficial to the taxpayer. Varying lower thresholds for determining relatedness and disallowing losses on transactions between related taxpayers permeate the United States tax law. ${ }^{170}$ And because the United States has had a graduated rate scale applicable to corporations, it also has an anti-abuse rule to prevent the proliferation of unconsolidated corporate taxpayers to capture multiple sets of graduated rates. ${ }^{171}$

\footnotetext{
${ }^{165}$ Married individuals may elect to file a joint return of their combined income. I.R.C. §6013. Whether or not married individuals elect to file jointly, their marital status affects the rates of tax applicable to each spouse. I.R.C. $\S 1(d)$. The marital status also prevents spouses from making different elections on itemization of deductions. I.R.C. $\S 63(c)(6)$.

${ }^{166}$ I.R.C. $\$ 1(\mathrm{~g})$ (tacking the investment income of minors to their parents' (or highest earning parent's) income for purposes of determining the rate of tax applicable to the minor.

${ }^{167}$ I.R.C. $\$ 267$ (disallowing losses on sales between certain family members among other transactions).

${ }^{168}$ Section 14(d)(2) of the Securities Exchange Act of 1934, as amended (the "Exchange Act"), 15 USCS 78n(d)(2) (defining person to include various people acting in concert in the acquisition of securities, whether or not they form a formal partnership or other entity).

${ }^{169}$ See discussion in text accompanying notes 161 to 163 supra.

${ }^{170}$ I.R.C. $\$ 267$, for example, denies losses to taxpayers who bear, directly or indirectly, a more than 50 percent ownership relationship to one another.

${ }^{171}$ I.R.C. $\$ 1561(a)(1)$ (denying multiple sets of rate brackets to component members of a controlled group of corporations defined in I.R.C. $\$ 1563$ as 80 percent parent-subsidiary ownership or when 5 or fewer persons (not including most entities) own a 50 percent overlapping voting ownership or value ownership).
} 
Regarding multiple taxpayers as a single taxpayer sometimes benefits the taxpayers by allowing them to use the losses of one to offset income of another. On other occasions, the conflation of taxpayers prevents them from controlling the placement of income with their transfer prices and the timing of the deductions that otherwise might arise from transactions between them. Careful planning sometimes permits taxpayers to seize the economic benefits but avoid the economic detriments of their relationships. In choosing a threshold of common ownership or relatedness, designers of the GUGIT must consider whether the GUGIT should follow the pattern of requiring a higher threshold for the benefits of consolidation than the threshold for disregarding separateness to prevent artificial diminution of tax liability. ${ }^{172}$ In the United States the use of differing thresholds to combat various tax planning opportunities has led to a cacophony of anti-avoidance type rules. ${ }^{173}$ Those loss disallowance and other antiavoidance rules target communities of interests that taxpayers exploit to diminish their tax liability. The CCCTB Proposal enhances its enterprise concept by embedding a transfer pricing anti-avoidance concept for transactions between enterprises that have overlapping control but are not members of the same group. ${ }^{174}$ The "community of interest" or "acting in concert" test that this paper recommends would provide the tax agency flexibility in identifying and preventing tax planning opportunities that inflexible numerical standards provide. ${ }^{175}$

Other approaches to the problem suggest themselves as well. Rather than relying on thresholds of overlapping ownership to prevent tax manipulation, the United States treasury regulations interpreting and supplementing the substantial economic effect partnership tax statute $^{176}$ turned to a present value analysis of the impact of allocations that did not correspond to the taxpayers' interests in the partnership. Under that regulation: ${ }^{177}$

\footnotetext{
${ }^{172}$ With the term "artificial" this paper refers to a tax structure that produces a tax benefit without affecting the underlying economic transaction. The CCCTB Proposal, supra note 37, Article 80 at 46 uses the "artificial" terminology in its anti-abuse rule.

${ }^{173}$ Some use a more than 50 percent test (I.R.C. $\$ 267$ for losses on sales between related entities); others an unspecified common control test (I.R.C. $\$ 482$ for transfer prices between commonly controlled entities and individuals). Many of the anti-avoidance rules include a series of complex constructive ownership rules. I.R.C. $\S 318$ applicable to I.R.C. $§ 302$ redemptions of shares, but I.R.C. $\$ 544$ uses different constructive ownership rules for determining the number of shareholders for personal holding company tax rules. .

${ }^{174}$ CCCTB Proposal, supra note 37, Articles 78-9 at 45 (defining associated enterprises and forcing accrual of income in transactions between associated enterprises where the transaction has conditions that differ from those that would have arisen in between unrelated taxpayers).

175 Taxpayers may assert, as they have with general anti-avoidance rules ("GAARs"), infra note 179 and accompanying text, that flexible standards leave uncertainty in the application of the tax laws in violation of constitutional standards. As with GAARs, such flexibility is essential to combatting the technically correct application of rigid tax rules for aggressive tax planning that has plagued the United States for many years. Ordower, Culture of Tax Avoidance, supra note 40, at 92.

${ }^{176}$ I.R.C. \$704(b) (requiring that partnership allocations of income and deduction among the partners in a partnership have substantial economic effect). The statute requires that allocations not having substantial economic effect be disregarded and the items of income and deduction be allocated according to the partners' interests in the partnership. The statute leaves to the Department of the Treasury the task of defining substantial economic effect. Treas. reg. \$1.704-1 and 2 seek to define substantial economic effect and provide a safe harbor of permissible allocation structures.

177 Treas. reg. $\S 1.704-1(\mathrm{~b})(2)(\mathrm{iii})(\mathrm{a})$ (providing rules on the substantiality of allocations).
} 
the economic effect of an allocation (or allocations) is not substantial if, at the time the allocation becomes part of the partnership agreement, (1) the after-tax economic consequences of at least one partner may, in present value terms, be enhanced compared to such consequences if the allocation (or allocations) were not contained in the partnership agreement, and (2) there is a strong likelihood that the after-tax economic consequences of no partner will, in present value terms, be substantially diminished compared to such consequences if the allocation (or allocations) were not contained in the partnership agreement.

Similarly, recognizing that tax planners are likely to find weaknesses in the CCCTB, the CCCTB Proposal embeds a general anti-abuse rule providing: "[a]rtificial transactions carried out for the sole purpose of avoiding taxation shall be ignored for the purposes of calculating the tax base."178 This anti-abuse rule is a member of the growing family of general anti-avoidance rules (GAARs) to which many jurisdictions have turned to help curb aggressive tax planning. ${ }^{179} \mathrm{~A}$ GAAR enables the taxing agency to look beyond the express statutory language to ascertain whether the economic substance of a transaction corresponds to its form and the intention of the statute itself.

It is probable that even if the GUGIT includes differing thresholds for combining taxpayers and disregarding tax avoidance transactions, the GUGIT nevertheless will need some kind of more general anti-avoidance provisions whether broad language like that of a GAAR, ${ }^{180}$ present value analysis like that of the United States partnership allocation rule, or the "acting in concert" standard. Without a GAAR, technical compliance with the GUGIT's rules will yield opportunities to structure around the purpose of the GUGIT. Rather than attempting to anticipate tax avoidance opportunities with detailed statutory rules, differing relationship thresholds for income and loss, and special mechanical rules, a principles-based approach like a GAAR would provide the greatest flexibility to combat unforeseeable tax planning opportunities. Insofar as the GUGIT redesigns thinking about taxes along global lines, traditional arguments against a GAAR $^{181}$ should give way to the need for a unified and effective approach to protect the integrity and fairness of this new taxing system.

C. Residence change and expatriation. To the extent that the GUGIT uses a residence concept in distributing income among jurisdictions and tax rates differ materially from one jurisdiction to another, taxpayers will try to avoid the higher tax jurisdiction by shifting residence. For corporations, where corporate residence is a function of place of incorporation and nominal headquarters, rather than actual place of management, change of the country of incorporation to reduce taxes is a sensible decision. If the residence test is a matter of the place

\footnotetext{
${ }^{178}$ CCCTB Proposal, supra note 37, Article 80 at 46 (ignoring artificial transactions carried out to avoid tax but not transactions representing alternative structures, one of which generates a more favorable tax outcome than another).

${ }^{179}$ For example, in Germany $\$ 42$ Abgabeordnung, in Sweden Skatteflyktslagen, in the United State I.R.C. §7701(o) (codifying an economic substance concept).

${ }^{180} \mathrm{Id}$. and for the present value test, supra note 177 and accompanying text.

${ }^{181}$ Supra note 175. Ambiguities of any statutory language creating uncertainty in application of a statute aside, most, perhaps all, taxpayers who structure to avoid the application of a specific statute know that they are avoiding taxes rather than altering the economic substance of their transactions. Ordower, Culture of Tax Avoidance, supra note 40 , at 98 .
} 
of actual management, a decision to relocate the corporation for tax purposes affects the physical location of the principal managers and becomes a far more difficult move.

In the case of an individual taxpayer, changing one's residence may have little significance if one may retain the national citizenship to which one has an emotional and linguistic bond. In fact, the change of residence might have independent significance ${ }^{182}$ like a retirement to a country with a more pleasant climate or a lower cost of living, rather than a tax avoidance purpose. ${ }^{183}$ Countries with territorial tax systems historically permitted their citizens and taxable residents to emigrate and free themselves from the home country's income taxes although increasingly countries have turned to continuation taxes to prevent tax emigrations. ${ }^{184}$

With its tax on worldwide income of citizens and permanent residents, the United States, on the other hand, requires that the citizen renounce her citizenship and emigrate in order to become free from the United States' income tax. ${ }^{185}$ Relinquishing one's citizenship would seem a much higher emotional price to pay to avoid taxes than simply changing one's residence while retaining citizenship. Nevertheless, some Americans do renounce. ${ }^{186}$

In order to combat change of residence to avoid taxes, countries have adopted two basic approaches: exit taxes and continuation taxes. An exit tax requires the taxpayer at the time of expatriation to include in income all the net gain the taxpayer would have included in income if she had sold her assets at their respective fair market values on the date of residence change or expatriation. ${ }^{187}$ Under a continuation tax, the departing or expatriating taxpayer, corporate or individual, remains subject to the income tax of the country from which she or it departed or expatriated for several years following the expatriation. ${ }^{188}$

The proposed formula for apportionment of trade or business income under the GUGIT removes most of the incentives for expatriating since it apportions income based upon some factors that remain unchanged following expatriation - destination sales and beneficial ownership. ${ }^{189}$ The underlying enterprise owners themselves would have to change residence or expatriate to shift the beneficial ownership factor to another country. As a practical matter, relocation of property and payroll to a low tax jurisdiction is likely to be a matter of business

\footnotetext{
${ }^{182}$ Supra note 133 and accompanying text on acts of independent significance.

${ }^{183}$ Many Canadians move to Florida for much of the winter (but tend to keep their period of residence under 183 days to avoid becoming U.S. residents for tax purposes). Many Americans retire to border areas of Mexico to capture the lower Mexican cost of living. Scandinavians, Germans, Dutch, and British select winter or all year residence in Spain and Mediterranean islands to avoid their harsh northern climates.

${ }^{184}$ Infra note 188 and accompanying text.

${ }^{185}$ Treas. reg. $\$ 1.1-1$ (a) (taxing resident and nonresident U.S. citizens on their worldwide incomes).

${ }^{186}$ Supra note 134.

${ }^{187}$ I.R.C. $\$ 877 \mathrm{~A}$ (imposing a tax on individual expatriations).

${ }^{188}$ I.R.C. $\$ 7874$ (taxing in the U.S. the inversion gain of an entity and defining inversion gain as gain from the sale of assets or income from licensing property to a related party for 10 years following expatriation); I.R.C. $\$ 877$ (taxing an expatriating individual on effectively connected income for 10 years following expatriation); 3 . Kap. $3 \S$ 3., 7 Inkomstskattelag (Sweden), supra note 109, (taxing expatriates on their income from all sources (obegränsad skattskyldighet) if they continue to have substantial connection with Sweden presumptively for 5 years following expatriation).

${ }^{189}$ Supra part 3.A.1. and 4.
}

(C) Copyright 2013 Henry Ordower

Utopian GUGIT Visions 
economics, lower wages and property costs, rather than tax avoidance. Similarly, if the GUGIT allocates an individual's income based on intended impact or relative periods of residence, ${ }^{190}$ change of residence or expatriation may have little effect on the taxpayer's tax rate on personal services income since both factors are independent of the taxpayer's permanent residence. Investment income follows residence more closely and is likely to shift with residence.

Given the centralization of tax reporting and collection, a continuation tax may be more administrable than an exit tax to counter tax departures and expatriations. A continuation tax does not require immediate asset valuations with their uncertainties for all but the most liquid assets. A continuation tax also requires taxpayers to cut ties with the home country if they wish to become free from the continuation tax. ${ }^{191}$ Ultimately, change of residence and expatriation will cease to be an issue if tax rates harmonize as one would expect them to do under a GUGIT.

D. Language and Currency Translation. There are six official languages of the United Nations: Arabic, Chinese, English, French, Russian and Spanish, ${ }^{192}$ but the EU operates currently in twenty-three official languages. However, the EU does not translate documents automatically into all twenty-three but relies primarily on English, French, and German as its procedural languages. ${ }^{193}$ The IRS provides some documents in Spanish, Chinese, Korean, Vietnamese, and Russian. ${ }^{194}$ The quality of computerized translation is imperfect but improving, ${ }^{195}$ and there is no reason to assume that the quality will not continue to improve over the next several years. The model of working in a handful of languages having wide usage and providing translation into other languages when needed seems a reasonable approach for the GUGIT.

English tends to predominate in international business transactions and has become an unofficial worldwide common language. ${ }^{196}$ Invariably, TIEAs have an English language official text based upon the OECD model. ${ }^{197}$ While this article does not suggest that the GUGIT use only English, as a practical matter, the group that will design the GUGIT is likely to conduct

${ }^{190}$ Supra part 3.A.5., especially text accompanying and following note 139.

${ }^{191}$ The U.S. continuation tax under I.R.C. $\$ 877(\mathrm{c})(2)(B)$ excepts dual nationals from the continuation tax only if they maintain no substantial contacts with the U.S. Similarly, the Swedish continuation tax holds expatriates to taxability in Sweden on their income from all sources for the 5 year continuation if they maintain significant contacts with Sweden, including, for example, continuing conduct of a trade or business, possession of a year round residence, family, and so forth. 3. Kap. $7 \S$ Inkomstskattelag (Sweden), supra note 109.

${ }^{192}$ UN Official Languages at http://www.un.org/en/aboutun/languages.shtml/.

${ }^{193}$ See Languages on the official EU website at http://ec.europa.eu/languages/languages-of-europe/eulanguages_en.htm where it explains: "[d]ue to time and budgetary constraints, relatively few working documents are translated into all languages. The European Commission employs English, French and German in general as procedural languages, whereas the European Parliament provides translation into different languages according to the needs of its Members."

${ }^{194}$ See the IRS Multilingual gateway at http://www.irs.gov/individuals/article/0,id=224594,00.html?navmenu=menu3.

${ }^{195}$ Google translate currently offers translation between 64 languages, including several substantially obsolete languages like Yiddish. Available at http://translate.google.com/.

196 Seth Mydans, Across cultures, English is the word, The New York Times (May 14, 2007); The triumph of English: A world empire by other means, The Economist (December 20, 2001) (available at http://www.economist.com/node/883997?Story_ID=883997).

${ }^{197}$ OECD model TIEAs, supra note 89. 
negotiations primarily in English ${ }^{198}$ and generate a single language text for the GUGIT initially before translating it into other languages. While translations into many languages may become necessary for users, presumably the GUGIT will have one or at most a handful of official primary texts to which other language users may refer if the translations into their languages are ambiguous or erroneous. Selection of the official language is politically charged, but historical negotiations to create an artificial international language always failed and people who have had to communicate in international settings generally have turned to French or English except when they had a closer common second language. ${ }^{199}$

Despite the existence of multiple numeral systems, ${ }^{200}$ most countries use the common European system of so-called Arabic numerals alongside any national system. Moreover, the GUGIT will rely on electronic numerals. Data processing translates data input (without regard to the numeral system appearing at the data entry point) into a common electronic data representation that can be translated into any numeral system without the uncertainties and ambiguities of language translation. Taxpayers and third party reporters will transmit primarily numerical data electronically in certain sequences or positions in order to comply with their obligations under a GUGIT. The electronic data entry protocols will reject data that does not sensibly fit the data entry field so that in most instances, language will be necessary only to the explanatory material to instruct the person entering the data how to use the data entry fields.

Undoubtedly there will be disagreements on interpretation of obligations that the taxing statutes create, as there always are with tax statutes, but translation of the statutes from one language to another seems unlikely to become a principal source of those disagreements. There probably will not be so much more interpretational uncertainty created by translation errors and ambiguities than there is today with the language of single country laws and regulations.

Currency translation may be a more serious concern than language translation, since relative currency values fluctuate from day to day while the meaning of words does not. For most taxpayers, currency translation will be unnecessary. Most will not engage in international commerce so their income will be in their local currency, as will be withholding, and the currency of the tax payment obligation. Computation of the tax base where income and expense involve multiple currencies is more problematic.

The CCCTB Proposal requires translation into the Euro of all transactions on the last day of the taxable year at the average rate of exchange that the European Central Bank determines for the year unless the company or enterprise is located in a single member state that does not use the Euro. ${ }^{201}$ Within the EU, the decision to use an average rate of exchange over a year's time makes sense because the other European currencies fluctuate within a narrow band relative to the

\footnotetext{
198 As the CCCTB WG conducted its negotiations.

${ }^{199}$ For example, the second language in the Soviet Republics historically was Russian, however, since the 1990 change in the economic systems, those former Soviet Republics increasingly have used English in business dealings if not governmental functions.

${ }^{200}$ Omniglot, Numerals in many different writing systems (available at http://www.omniglot.com/language/numerals.htm) (listing 23 different numeral systems).

${ }^{201}$ CCCTB Proposal Article 22, 2, supra note 37 at 26. 
Euro. ${ }^{202}$ The region is monetarily stabile. A worldwide tax base will be more complicated since currency translation goes to both the distribution of the base and the use of withheld and estimated tax payments. Instability of currencies and lack of convertibility are both problematic. The problem of convertibility no longer is insurmountable. All major currencies currently are either convertible or on their way to full convertibility. ${ }^{203}$

While a common international currency ultimately might follow from a GUGIT, until that happens it will be necessary to convert all transactions into a single measure in order to facilitate distribution of the tax base. The taxpayer may select a functional currency for reporting revenue and expenditures. Regular use of an artificial currency pegged to a major world currency, usually the United States dollar or the Euro has become commonplace. ${ }^{204}$ Several countries use the United States dollar for their currency in order to control exchange rate fluctuations that historically plagued their own currencies. ${ }^{205}$ Frequently, businesses in countries with unstable currencies state prices in a major, stable currency but then convert at the rate of exchange at the moment of sale. ${ }^{206}$ Taxpayers also might choose their home jurisdiction's currency because the taxpayer maintains books and records in that currency.

Formulary distribution of income among taxing jurisdictions requires relative currency stability unless the taxpayer never actually uses money earned in one jurisdiction to pay expenses in another. In the absence of cross-border payments, translation of income and expenditure at an average rate should result in a correct distribution of income and tax burden. ${ }^{207}$ In the presence of cross border expenditures, however, use of an average rate of exchange over a full annual accounting period only works well in the context of narrow band currency fluctuation such as

\footnotetext{
${ }^{202}$ EC, Economic and Financial Affairs, What is ERM II? (available at http://ec.europa.eu/economy_finance/euro/adoption/erm2/index_en.htm). Members of ERM II, most of which joined the Euro zone, agreed to a maximum fluctuation within fifteen percent. Denmark maintains the range at 2.25 percent and Latvia at 1 percent. The UK and Sweden are not part of ERM II, but the Swedish krona generally fluctuates relative to the euro within the 15 percent range from the base rate, but the UK pound sterling has fluctuated more widely from its base rate.

${ }^{203}$ Bloomberg News, Yuan Will Be Fully Convertible by 2015, Chinese Officials Tell EU Chamber (September 8, 2011) (available at http://www.bloomberg.com/news/2011-09-08/yuan-to-be-fully-convertible-by-2015-euchamber.html) (announcing a target for full Yuan convertibility); Reserve Bank of India, Annual Report, V. Development and Regulation of Financial Markets, see the Capital Account portion of the report (available at http://www.rbi.org.in/scripts/AnnualReportPublications.aspx?Id=984) (discussing liberalization of the capital markets and convertibility).

${ }^{204}$ For example, the Asian Clearing Union permits clearance of transactions either in ACU dollars or euros. See the Asian Clearing Union website at http://www.asianclearingunion.org/Introduction.aspx.

${ }^{205}$ Most recently, Ecuador.

${ }^{206}$ Zambia, for example.

207 To illustrate: taxpayer elects currency A as its functional currency. Taxpayer earns 1000 units of net income in currency A, and 100 units of net income in currency B as well. On the first day of the year, currencies A and B traded at one to one, on the last day of the year A and B trade at 10 to one and the average for the year is eight to one. Taxpayer earned the 100 units of B on the first day of the year and 1000 units of income in currency A on the last day of the year. The average exchange rate for the year is the 8 to 1 . Assume countries $\mathrm{A}$ and $\mathrm{B}$ have a $50 \%$ tax rate. Using the average exchange rate and the taxpayer's functional currency, the taxpayer earned 800 units of $\mathrm{A}$ in country B, and 1000 units of A in country A, even though when earned the amounts were identical in value. The GUGIT would allocate 5/9 of the tax base of 1800, 1000 units to country A for a 500 unit tax (the correct amount), and 800 to $\mathrm{B}$ translated at the average rate of 8 to $100 \mathrm{~B}$ units for a tax of $50 \mathrm{~B}$ units (also correct).
} 
that present in the EU and its member states. ${ }^{208}$ Average exchange rates work less well when a currency lacks a ready foreign exchange market because the country has a high rate of inflation or the economy and, accordingly, the currency otherwise is unstable. In those instances, where a taxpayer uses one currency to pay an expense in another currency, the tax base distribution works correctly if the taxpayer uses a cash basis of accounting and the actual exchange rates of currency conversion. Government restrictions on outbound convertibility further complicate distribution of income and payment of taxes outside the restricted country. ${ }^{209}$

Fixed exchange rates would permit the GUGIT to distribute income among jurisdictions seamlessly and fairly, but those fixed exchange rates must be a function of stabile economies rather than artificial controls that depart from economic reality. A single worldwide currency is the best choice in light of increasing interconnectedness of national economies.

Part 4. Toward Uniform Tax Rules. A GUGIT requires uniform rules of inclusion and deduction in the income producing portion of the taxpayer's world. ${ }^{210}$ Variations in those rules from jurisdiction to jurisdiction frustrate the GUGIT's objective of eliminating the possibility of both multiple inclusions of the same income and no inclusion of income in any jurisdiction. The GUGIT must construct a single tax base to distribute among the jurisdictions in which the taxpayer is active. A simple example might be that commuting expenses be uniformly deductible or non-deductible as business expenses. ${ }^{211}$ If the GUGIT design makes commuting expenses non-deductible, a country would remain free to allow them against that country's share of the uniform tax base but could not take them into account in determining the distributable tax base itself.

The states of the United States have used formulary apportionment for many years. They have employed the federal income tax base as a uniform point of departure for apportionment ${ }^{212}$ but have failed to achieve complete uniformity of base and apportionment formula. ${ }^{213}$ Each state adjusts the federal base in state specific ways to construct its own tax base to apportion according to its apportionment formula. The CCCTB Proposal, on the other hand, lays down principles for the computation of a single uniform tax base without country specific variations. ${ }^{214}$ While the

\footnotetext{
208 See note 202 supra.

${ }^{209}$ Governments do not restrict inbound movement of foreign exchange although many have prohibited their citizens from holding foreign exchange, thus requiring conversion into the local currency for legal receipts of foreign exchange, for example, all the Soviet bloc countries before 1990.

${ }^{210}$ Countries may provide additional deductions for the non-income producing part of the taxpayer's world. These deductions in U.S. tax parlance would fit into the current group of itemized (or below the line) deductions under I.R.C. $\$ 63$ and might include such items as a deduction for the interest on a home mortgage.

${ }^{211}$ U.S. tax law considers commuting expenses to be personal, living, and family expenses that under I.R.C. $\$ 262$ are non-deductible. German tax law views commuting costs as necessary to the taxpayer's income production and, accordingly, deductible. Einkommensteuergesetz (Neugefasst durch Bek. v. 8.10.2009 I 3366, 3862; zuletzt geändert durch Art. 3 G v. 8.5.2012 I 1030) (German Income Tax Law) §9, II1, Nr. 4 (permitting a deduction for commuting costs as trade or business expenses).

${ }^{212}$ The state of Missouri, for example, commences the computation of the corporate tax with federal taxable income and then makes modifications applicable to Missouri before apportioning the income. Form MO-1120, line 1- 4 (federal taxable income and modifications), line 10 (apportioned Missouri taxable income) (available at http://dor.mo.gov/forms/MO-1120_Fillable_2011.pdf).

${ }_{213}$ Supra, note 99 and accompanying text.

${ }^{214}$ Supra, note 37, Chapter IV at 22-24.
} 
concept of a multi-national uniform tax base might have seemed unimaginable in the past, broad acceptance of the CCCTB Proposal, albeit with modifications, ${ }^{215}$ brings the concept into the imaginable.

Both accounting principles and substantive tax rules now tend to converge across national borders. While the United States applies generally accepted accounting principles, a rule based system of financial reporting, to public disclosure, European and other countries use the principles based system of the international financial reporting standards. Whenever a United States issuer of securities included financial results from a European affiliate in its financial statements or a non-United States issuer wished to list its securities on a United States exchange, they had to translate the accounting results from IFRS to GAAP. The converse also was true for issuers based in the United States and using GAAP but wishing to list in Europe. In 2008, however, the SEC announced and published a "Roadmap" for use of IFRS by United States issuers possibly as early as $2014 .^{216}$ In the Roadmap the SEC acknowledged that increasing integration of international financial markets and international acceptance of IFRS made it necessary for the United States to consider seriously whether adoption of IFRS would be in the best interests of United States issuers and their shareholders. ${ }^{217}$ Although the SEC's final staff report on IFRS did not conclude that IFRS would be in the best interests of United States issuers and shareholders, neither did it reject continuing convergence and future possible transition to IFRS. The report recommends continuing SEC involvement with development of IFRS. ${ }^{218}$ Convergence and integration of financial reporting standards worldwide certainly is in process but possibly at a slower pace than earlier SEC statements suggested.

The last several decades also have seen increasing borrowing of substantive tax rules and convergence of tax concepts. While the CCCTB Proposal perhaps is the most immediately visible of the developments, the decade of the 1990s saw the construction of income tax systems in the formerly centrally planned economies of the Soviet republics and satellite states. Tax experts from free market economic systems assisted in the development of the new tax systems and modeled them from their own experience. ${ }^{219}$ Similarly, the CCCTB WG solicited the views of experts from many countries in constructing the CCCTB. Inevitably neither the tax systems in the former Soviet sphere of influence nor the CССТВ copied any single existing tax system. Rather both projects were convergence projects that selected elements from several systems.

In many instances, systems and concepts converge as countries experience similar problems or concerns with their systems and look to other countries for possible solutions. Legislatures and courts have examined debates and decisions in other countries for guidance on

\footnotetext{
${ }^{215}$ EP CCCTB resolutions, supra note 38.

${ }^{216}$ SEC Proposed Rulemaking, Roadmap, supra note 12.

${ }^{217} \mathrm{Id}$

${ }^{218}$ SEC, Final Staff Report, Work Plan for the Consideration of Incorporating International Financial Reporting Standards into the Financial Reporting System for U.S. Issuers, supra note 12 (July 13, 2012).

${ }^{219}$ Jorge Martinez-Vazquez and Robert M. McNab, The Tax Reform Experiment in Transitional Countries, 53 NATIONAL TAX JOURNAL 273 (2000) (describing tax reform approaches and international assistance in tax reform in the formerly centrally planned economies); Yolanda K. Kodrzycki and Eric M. Zolt, Tax Issues Arising from Privatization in the Formerly Socialist Countries, 25 LAW \& POL'Y INT'L BUS. 609 (1994) (discussing importance of taxation to stable economies and the development of tax systems there).
} 
and solutions to problems that confront them as well as the legislatures and courts of the other countries. Among striking examples of this phenomenon are GAARs ${ }^{220}$ and controlled foreign corporation (CFC) rules. ${ }^{221}$ Neither GAARs nor CFC rules are identical in all jurisdictions but all have fundamental similarities. GAARs empower the tax administrator to disregard the form of a transaction having a tax avoidance purpose and substitute a different tax outcome than that the taxpayer wanted, ${ }^{22}$ CFC rules prevent some shifting of income to low tax jurisdictions where a compelling business reason for the placement of the income is absent. The income has no immediate relationship with the jurisdiction in which it arises. Similarly, the OECD has taken on several anti-tax avoidance projects that tend to make rules across national borders more uniform, including transfer pricing methodologies ${ }^{223}$ and exchanges of tax information. ${ }^{224}$ In addition, the stark historic differences between schedular and global tax systems have tended to converge into hybrid systems, ${ }^{225}$ while rate competition has reduced corporate and often individual income tax rates throughout most of the economically, developed world.

While nations continue to enact and maintain tax rules that differ from those of other nations, most of those rules exist as a matter of internal political compromise rather than as reflections of deeply embedded fundamental national principles that render them unalterable. Even when exhibiting clear policy choices, the rules are details not basic structural elements of an income tax system. Resistance to enactment of a GUGIT will come as no surprise, but that resistance is likely at best to reflect principled differences of opinion with the GUGIT design group's negotiated compromises on specific tax rules and at worst political posturing alongside some fear of sacrificing national autonomy. Thus, if local enactment of an internationally designed GUGIT leaves nations the choice of accepting or rejecting the GUGIT as a whole only, ${ }^{226}$ leaving no opportunity to reject or modify specific items of the GUGIT, countries are less likely to isolate themselves by refusing to join if their neighboring states and major economic powers join.

Part 5. Economic Displacement from the New GUGIT. In 1981 when the United States enacted favorable new tax rules for depreciation, the average price of depreciable real property

\footnotetext{
${ }^{220}$ Supra, note 175 and accompanying text.

${ }^{221}$ See, generally, KPMG LLP, Controlled Foreign Company Taxation Regimes in Selected Countries: Report Prepared for the Advisory Panel on Canada's System of International Taxation (April 2008) (available at http://www.apcsit-gcrcfi.ca/06/rr-re/RR5\%20-\%20KPMG\%20-\%20en\%20-\%20final\%20-\%20090608.pdf) (describing the controlled foreign corporation rules in 10 countries, which either attribute the controlled foreign corporation's income to domestic shareholders or impose a domestic tax on the corporation to reflect its domestic ownership).

${ }^{222}$ Ordower, Culture of Tax Avoidance, supra note 40, at 94-103 (discussing the growth of GAARs internationally).

${ }^{223}$ OECD, TRANSFER PRICING GUIDELINES, supra note 24 (providing guidelines for transfer pricing restraints); and the OECD announced its intention to publish a white paper on standardization and simplification of transfer pricing documentation. Julie Martin, OECD to Tackle Transfer Pricing Documentation, 2012 TNT 149-4 (August 2, 2012 ).

${ }^{224}$ OECD, Harmful Tax Competition, supra note 8 and model TIEA, supra note 87.

${ }^{225}$ Sylvain R.F. Plasschaert, SchEDULAR, GLOBAL AND DUALISTIC PATTERNS OF INCOME TAXATION 17-24 (1988) (discussing schedular tax systems); Eric M. Zolt, The Uneasy Case for Uniform Taxation, 16 VA. TAX REV. 39, 4950 (1996).

${ }^{226}$ A problem with uniform laws is that jurisdictions often modify features of those laws so that they are not truly uniform from jurisdiction to jurisdiction.
} 
increased $x$ percent, ${ }^{227}$ and depreciable real property similarly lost value when the depreciation rules became less favorable again. ${ }^{228}$ When the rules became more favorable, owners of depreciable real property received a windfall gain if they sold the property insofar as they bought their property when rules were less favorable, and, accordingly, commanded a lower price. When the depreciation rules became less favorable, owners of depreciable real property suffered a loss in value of their properties. That loss in value probably was particularly noticeable to those who acquired their properties during the period of more favorable rules when there was a spike in value. At the time of each change in depreciation rules, there were economic displacements. Changing rules causes those displacements although well-functioning markets anticipate changes and take them into account gradually or sooner than the change event so that the displacements are less remarkable.

Changes require other changes to compensate for the first changes. When the United States tax depreciation rules became more favorable, income tax revenues from the operation of real estate declined. On the other hand, initially there may have been more sales of real estate at taxable gains because a purchase would enable the purchaser to use the new, favorable depreciation rules and the seller to capture the spike in value that the rule change created. If the tax from gain did not offset the loss of revenue from favorable depreciation rules, other rule changes or rate changes would become necessary to make up for the lost tax revenue so that the government could continue to provide services. From time to time rules for budgeting tax changes that diminish revenue in the United States require revenue offsets. Under those rules a legislator may not introduce legislation to increase an existing or create a new tax benefit without complementary legislation to offset the revenue loss. ${ }^{229}$ Revenue neutrality for tax changes does not mean revenue neutrality for taxpayers. Changes create winners and losers even if on a governmental revenue measure no change occurred. Stabile rules do not.

Economic displacements will accompany the shift to a GUGIT. Economic displacements also accompany any change in substantive tax laws (and probably procedural tax laws as well). ${ }^{230}$ Taxpayers, who have exploited tax planning opportunities such as transfer pricing to shift income to low tax jurisdictions, will lose that tax avoidance opportunity and probably pay more tax. Those taxpayers arguably should not have had the opportunity to shift income in the first instance. In addition, the diminished deadweight loss of tax planning and tax administration to prevent such tax planning offsets some or all the economic displacement although the beneficiaries of the economic benefit may not be identical with those losing the tax planning benefit. Like all tax changes, adoption of the GUGIT will produce winners and losers.

For the average taxpayer, little will change. Enhanced withholding under the centralized collection system may deprive some taxpayers of the financial float they enjoyed by waiting until

\footnotetext{
${ }^{227}$ Marcus \& Millichap, Research Review Trends Report: Commercial Real Estate Review: 30 Year Look Back (available at http://vitorinogroup.com/wp-content/uploads/2012/02/CommercialREReview.pdf) (discussing impact of tax law changes on commercial real estate).

${ }^{228} I d$.

${ }^{229}$ The Budget Enforcement Act of 1990 was Title 13 of the Omnibus Budget Reconciliation Act of 1990, Pub.L. 101-508) (including pay as you go rules (Paygo) requiring tax legislation that reduced revenue to include an offsetting revenue increase).

${ }^{230}$ Supra, note 227 and accompanying text. 
tax payment time to pay. ${ }^{231}$ Exclusions and inclusions in income may not be identical to what they are currently, but most of the changes will not have a recurrent effect on any specific taxpayer. If there is a strong policy reason for a specific exclusion - subsidization at national level for local governments through the interest exclusion, ${ }^{232}$ for example - a direct subsidy would work equally well possibly without as much deadweight loss. ${ }^{233}$

Changes in the cost recovery rules, depreciation and amortization, may cause more significant economic displacement as they alter the underlying value of property. Yet, if the United States is representative of the frequency with which the legislature alters those rules, the resulting economic displacement if far from unusual.

More significant for countries that tax on worldwide income, like the United States does, might be the implicit shift to territoriality. Those countries will receive their shares of the taxpayer's uniform tax base but not the bonus over the tax rate that other countries may charge on their shares of that base. ${ }^{234}$ On the other hand, the United States is likely to be on the receiving end of tax base on the destination sales and beneficial ownership factors in the formula. Disruption of taxpayers' opportunity to shift income through transfer pricing is also likely to increase the share of the tax base allocated to the United States, so that the "deferral" opportunity diminishes $^{235}$ and temporary tax reductions to encourage repatriation of earnings become unnecessary. ${ }^{236}$

Part 6. Conclusion. Transfer pricing regulation has failed to prevent taxpayers from shifting income to low tax jurisdictions, as tax administrators have struggled to challenge those prices. GAARs have proliferated worldwide suggesting that existing tax laws are inadequate to staunch loss of revenue through sophisticated tax planning. Commerce has become increasing global and

\footnotetext{
${ }^{231}$ With current interest rate levels, it is difficult to imagine any significant value to the float from short term tax deferral.

${ }^{232}$ I.R.C. $\$ 103$.

${ }^{233}$ If in order to sell local government tax exempt bonds, the interest rate must target an income group not subject to the highest marginal rate of tax, investment in the bonds by a taxpayer subject to the highest rate of tax results in deadweight loss because it shifts part of the subsidy value to the high bracket taxpayer and away from the subsidized local government.

${ }^{234}$ The U.S. computes the tax liability of its citizens and residents on their worldwide income (I.R.C. §61 (including income from all sources worldwide)) and allows a credit for taxes paid to foreign countries under I.R.C. §901. Whenever the U.S. rate exceeds the foreign rate of tax, the U.S. retains the excess of the U.S. tax on the foreign income over the creditable foreign tax,

${ }^{235}$ Since a corporation's earnings from the active conduct of business generally are not taxable to its shareholders until distributed, unless an anti-avoidance rule like the passive foreign investment company (I.R.C. §1291 et seq.) or controlled foreign corporation (I.R.C. $\$ 951$ et seq.) rules apply, corporate taxpayers seek to defer U.S. taxes by shifting income offshore, especially through transfer pricing arrangements.

${ }^{236}$ In 2004, U.S. legislation effectively reduced the U.S. tax rate repatriated earnings of a controlled foreign corporation to a maximum of $5.25 \%$ temporarily for a single tax year to encourage investment in the U.S. and increase employment in the U.S. The rate reduction resulted from a dividends received deduction of 85 percent of the amount of the dividend if the recipient invested the funds in the U.S. under a domestic reinvestment plan. I.R.C. $\S 965$ (added by the American Jobs Creation Act of 2004, PL 108-357 (Oct. 22, 2004). Proposed legislation in 2011 would repeat the decreased rate on repatriation even though the earlier effort seems to have accomplished little to stimulate the U.S. economy. The concept, however, is that deferral traps the revenues offshore and only a rate reduction would free them for U.S. use.
} 
business ownership no longer national. With growing regularity, enterprises reach across national borders to acquire other enterprises, even very large ones. Against the backdrop of internationalization of commerce, taxation only on a national level seems strangely anachronistic. While not pushing for a global tax regime, tax administrators and national legislatures have increased international access to the domestic tax information gathering power. Treaties and TIEAs require transmission of large quantities of taxpayer data from national tax administrations to tax administrations in other countries.

OECD projects on harmful tax competition ${ }^{237}$ and transfer pricing, ${ }^{238}$ the United States' and other countries' prosecutions for concealment of assets and income abroad, negotiations with various jurisdictions for changes in bank secrecy laws, enactment of FATCA, tax administrators' purchase of stolen secret financial information, and the CССТВ Proposal ${ }^{239}$ all emphasize the critical importance of international cooperation on tax matters. Jurisdictions have become less protective of their national sovereignty on tax matters. ${ }^{240}$ The CCCTB Proposal opens the door to cross border tax administration. The momentum to replace obsolescent domestic taxation with global taxation reflecting global commerce is growing. A progressive income tax remains conceptually fair and desirable, but the international trend is toward more administrable, and regressive, consumption and labor taxes. A GUGIT might protect the progressive income tax and contribute to long term development of global markets with uniform tax rules free from the deadweight loss of resources to tax planning.

The limited purpose of this paper has been to identify many of the global conditions that lend themselves to and to present a framework for GUGIT development. The paper's recommendations are utopian or dystopian depending upon the impact that a GUGIT might have on the individual reader.

\footnotetext{
237 Supra note 8.

${ }^{238}$ Supra note 158

239 Supra note 37.

${ }^{240}$ See, generally, Roman Seer and Isabel Gabert, general reporter and ed., MUTUAL ASSISTANCE AND INFORMATION EXCHANGE (Amsterdam, 2010) (assembling and compiling national reports on exchange of information and mutual assistance in tax matters from various European jurisdictions and the United States for the 2009 meeting of the European Association of Tax Law Professors).
} 